\title{
STRAIN MONITOR SYSTEM FOR THE THREADED CLOSURE ON A THIRTY-INCH PRESSURE VESSEL
}

S. L. Chapman

J. A. Kowalewski

C. R. Olmstead

PORTIONS QR THIS REPORT ARE TLLEGIBIE. It has been reproduced from the best available copy to permit the broadest possible ava1l m ability.

prepared for the U.S. ENERGY RESEARCH AND DEVELOPMENT ADMINISTRATION under U.S. GOVERNMENT Contract W-7405 eng 26

\section{MASTER}




\section{DISCLAIMER}

This report was prepared as an account of work sponsored by an agency of the United States Government. Neither the United States Government nor any agency Thereof, nor any of their employees, makes any warranty, express or implied, or assumes any legal liability or responsibility for the accuracy, completeness, or usefulness of any information, apparatus, product, or process disclosed, or represents that its use would not infringe privately owned rights. Reference herein to any specific commercial product, process, or service by trade name, trademark, manufacturer, or otherwise does not necessarily constitute or imply its endorsement, recommendation, or favoring by the United States Government or any agency thereof. The views and opinions of authors expressed herein do not necessarily state or reflect those of the United States Government or any agency thereof. 


\section{DISCLAIMER}

Portions of this document may be illegible in electronic image products. Images are produced from the best available original document. 
Reference to a company or product name does not imply approval or recommendation of the product by Union Carbide Corporation or the U.S. Energy Research and Development Administration to the exclusion of others that may meet specifications.

Printed in the United States of America. Available from National Technical Information Service

U.S. Department of Commerce

5285 Port Royal Road, Springfield, Virginia 22161

Price: Printed Copy $\$ 5.45$; Microtiche $\$ 2.25$

$$
5.9
$$

This report was prepared as an account of work sponsored by the United States Government. Neither the United States nor the Energy Research and Development Administration, nor any of their employees, nor any of their contractors, subcontractors, or their employees, makes any warranty, express or implied, or assumes any legal liability or responsibility for the accuracy, completeness or usefulness of any information, apparatus, product or process disclosed, or represents that its use would not infringe privately owned rights. 
Date of Issue: June 9, 1976

Report Number: Y-2040

Distribution Category:UC-37 \& UC.38

\title{
STRAIN MONITOR SYSTEM FOR THE THREADED \\ CLOSURE ON A THIRTY-INCH PRESSURE VESSEL
}

\author{
S. L. Chapman \\ J. A. Kowalewski \\ C. R. Olmstead \\ Physical Testing Department \\ Y-12 Product Certification Division
}

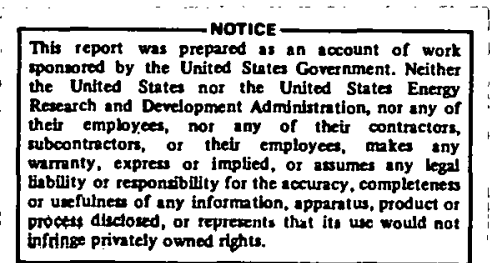

Oak Ridge Y-12 Plant

P. O. Box Y. Oak Ridge, Tennessee 37830

Prepared for the US Energy Research and Dovelopment Administration

Under US Government Contract W-7405-eng-26 


\begin{abstract}
A system has been designed and fabricated to remotely measure and automatically print voltages proportional to strains experienced by the internal threaded areas of the closure on a 30-inch pressure vessel in the Oak Ridge Y-12 Plant. This system was designed to provide continuous monitoring during pressure vessel use and thereby provide a faster response to possible vessel failure, should the data indicate a weakening of the pressure vessel closure. Standard 120-ohm foil strain gages in a wheatstone-bridge configuration are utilized with an integrated circuit instrumentation amplifier and multiplexing logic installed within the vessel closure to minimize the wiring problems. The system has performed satisfactorily and has provided data on 15 gages located within the closure.
\end{abstract}




\section{CONTENTS}

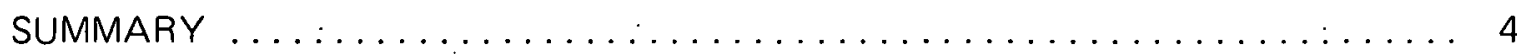

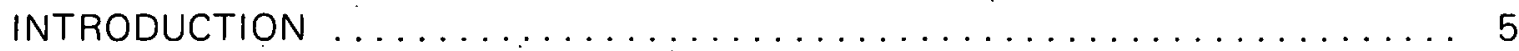

THREADED CLOSURE STRAIN MONITOR SYSTEM $\ldots \ldots \ldots \ldots \ldots \ldots \ldots \ldots$

System Design and Fabrication $\ldots \ldots \ldots \ldots \ldots \ldots \ldots \ldots \ldots \ldots \ldots \ldots \ldots \ldots \ldots \ldots \ldots \ldots$

Prototype Design ............................... 6

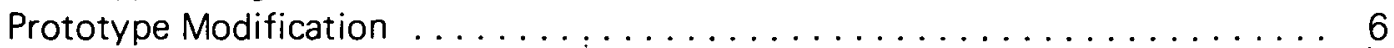

Final Design ................................ 7

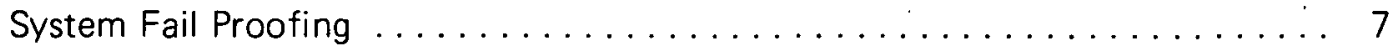

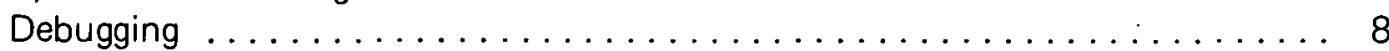

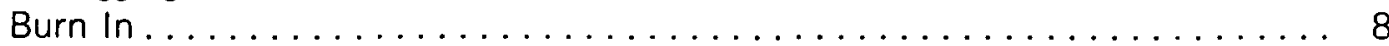

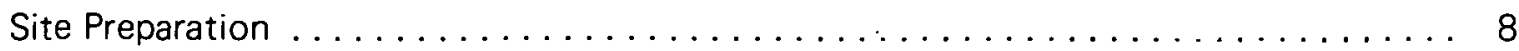

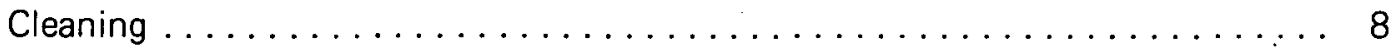

Ultrasonic Inspection ............................... 9

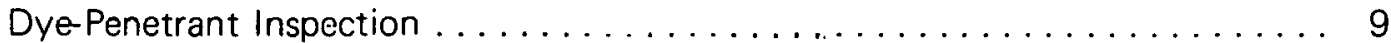

System Installation ..................................... 10

Gage ..................................... 10

Lead Wire .................................... 11

Electronics ..................................... 12

Calibration ....................................... 17

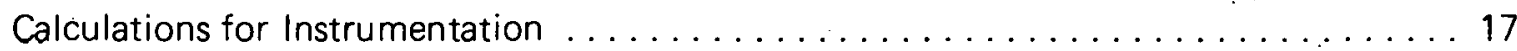

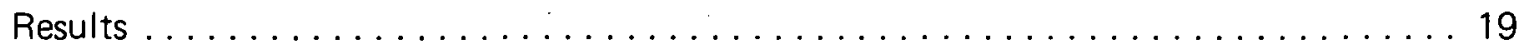

CONCLUSIONS AND RECOMMENDATIONS $\ldots \ldots \ldots \ldots \ldots \ldots \ldots \ldots \ldots$

REFERENCES...................................... 21

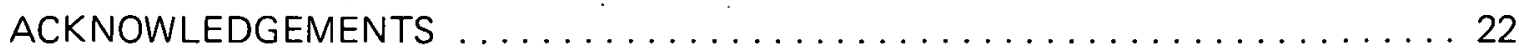

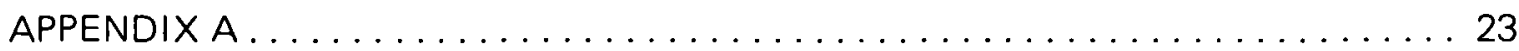

Program to Calculate System Calibration Data $\ldots \ldots \ldots \ldots \ldots \ldots \ldots \ldots \ldots \ldots .23$

APPENDIX B ......................................... 24

Program to Convert System Output to Strain Data ................... 24

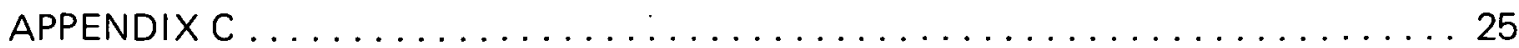

Program to Output Data File from the Previous Test $\ldots \ldots \ldots \ldots \ldots \ldots \ldots \ldots 25$

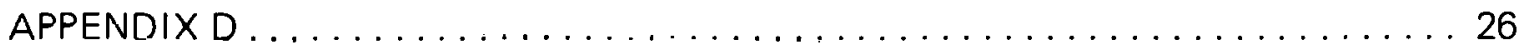

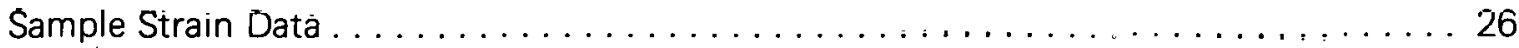

APPENDIXE ....................................... 35

Program to Plot Comparison Data $\ldots \ldots \ldots \ldots \ldots \ldots \ldots \ldots \ldots \ldots \ldots \ldots \ldots \ldots \ldots \ldots$

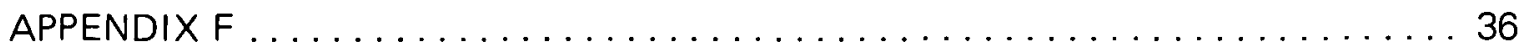

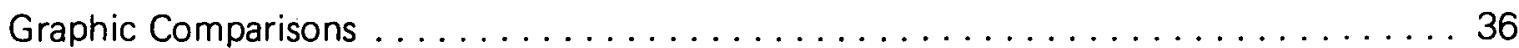

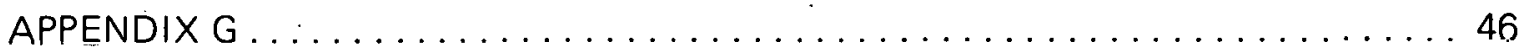

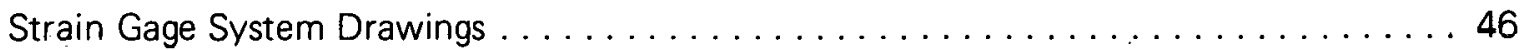




\section{SUMMARY}

Pressure vessels used in autoclave work are subjected to large working pressures and are susceptible to catastrophic failure if conditions develop which might weaken the vessel components. The most probable area in which these conditions could arise is in the closure areas, due to fabrication techniques. A visual inspection is impossible without disassembly, thus the need arises for a dynamic testing technique which may be used to study the vessel while under operating conditions.

A system which monitors the dynamic conditions in a 30 -inch pressure vessel closure area was installed and evaluated.

Results of the evaluation can be summarized as follows:

1. Electronic state of the art allows design and fabrication of a totally enclosed, remote monitoring system.

2. Generation and transmission of analoy data to a remote analog/digital converter and printer over a line length of 200 feet is possible without line-loss orrors.

3. Remote measurement and multiplexing of analng data in a closed eirvirurment is rédsible.

4. Remotely acquired strain-gage data are accurate and repeatable. 


\section{INTRODUCTION}

Recently, the gas autoclave (designated as PV-2) was taken off line for overhaul and maintenance. The autoclave's lower closure was previously instrumented for strain measurements in the thread roots. These measurements were previously taken manually on an infrequent basis to determine strain conditions at strategic vessel locations. Improvement of the strain monitoring system was requested prior to placing the vessel off line.

An automatic strain monitoring system was designed and installed to provide for: (1) a reduction in cabling, (2) remote sensing and display of strain conditions, (3) reduction of data acquisition and analysis time, and (4) on-call data acquisition by operating personnel.

This report deals with the design, fabrication, and installation of such a system in the Oak Ridge Y-12 Plant. (a)

(a) Operated by the Union Carbide Corporation's Nuclear Division for the US Energy Research and Development Administration. 


\section{THREADED CLOSURE STRAIN MONITOR SYSTEM}

\section{SYSTEM DESIGN AND FABRICATION}

The 30-inch pressure vessel (PV-2), located in the Oak Ridge $Y-12$ Plant, was taken out of service for overhaul and modification in late 1973. During early planning discussions of work which would be required to reinstrument the threaded closure, a request was made to determine the feasibility of providing a monitoring system that was automatic in nature and would provide data faster than the manual reading system which was then in use.

As first presented, the request was for a radio-frequency telemetry system totally enclosed within the vessel closure area. However, this mothod was impussible due to the solıd steel enclosure formed when the vessel was sealed: alsn, it was impossiblo to transmit thruigili liut steel walls. The method proposed and selected for installation was one which located wheatstone bridges and amplifier circuits with analog multiplexers internal to the closure area, but the display and printer were remotely located.

\section{Prototype Design}

A prototype of the required bridge and amplifier circuit was assembled and put under test to determine the functions, controls, and component requirements that must be given consideration in the final design. A simplified schematic of the circuit is given in Figure 1.

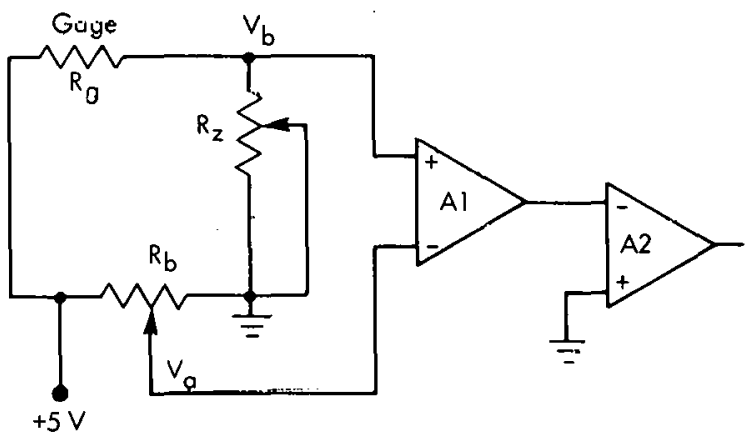

\section{Prototype Modification}

Figuié 1. PROTOTYPE B̈HIIU,IAMPLIFIER.

The bridge halves in the initial circuit were formed by $R_{g}$, one half of $R_{b}$ and $R_{z}$, and one half of $R_{b}$. In order to reduce sensitivity of the circuit tn adjusstment of $R_{b}$ und $R_{L}$, the circult was modified to that shown in the final circuit of Figure 2. These modifications provided the ability to very precisely establish $V_{a}$ and $V_{b}$ when initializing the circuit for measurements.

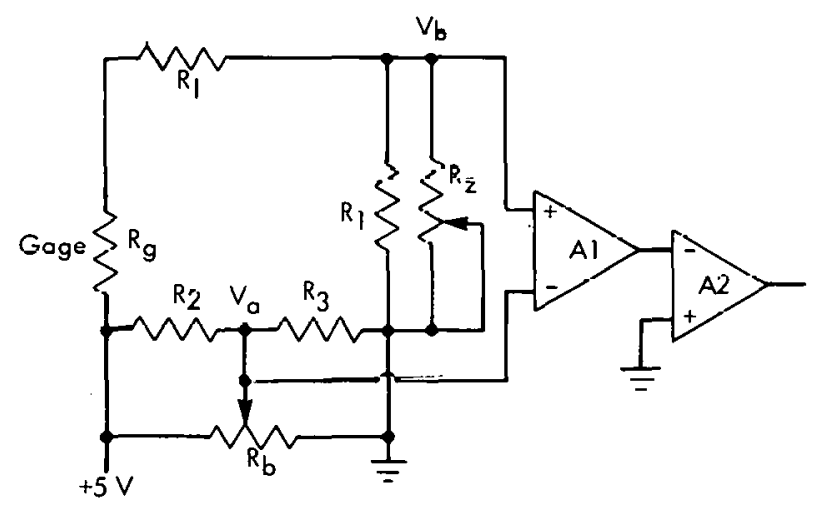

Figure 2. MODIFIED BRIDGE/AMPLIFIER.
All additional moditication to the circuit was to replace the original potentiometers $\left(R_{b}\right.$ and $\left.R_{z}\right)$ with components huving $50 \mathrm{ppm} / \mathcal{C} \mathrm{C}$ drift. This change was necessary due to the high gain of the amplifier stages.

Evaluation of the prototype circuit proved the feasibility of providing low-drift bridge and amplifier circuits to monitor strain. At this point, the concept was assigned to $Y$-12 Engineering for final design and fabrication. 


\section{Final Design}

During final design, the only major circuit change was the use of Analog Device's AD520K instrumentation amplifier. This change reduced the circuit physical size by a factor of 5 . Figure 3 presents the final circuit configuration as installed. Each bridge and amplifier. circuit board contained four circuits for measuring strain.

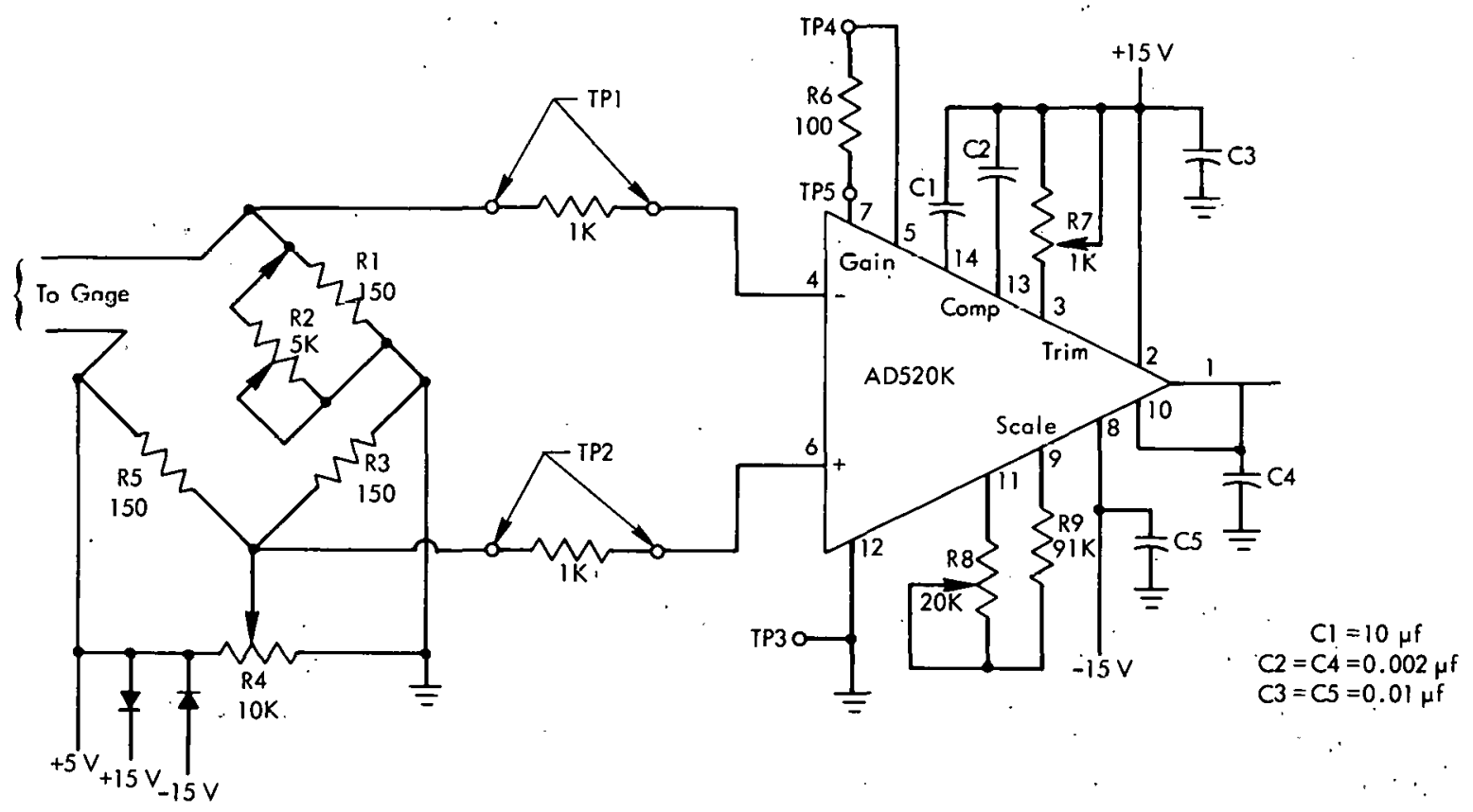

Figure 3. DESIGN BRIDGE/AMPLIFIER SYSTEM.

The second major portion of the system was the multiplexing and analog-to-digital conversion system which was used to select and digitize the appropriate amplifier output for display and printing. A block diagram of the clock and multiplexing circuit is given in Figure 4.

The signals between the control console and the enclosed circuit cards were transmitted for a distance of approximately 200 feet. For this reason, digital signals were transmitted with a DEC A 207 operational amplifier used as a line driver.

The analog signals representing strain, after conversion, are displayed on a LED display and printed on a Systron. Donner Model 5013B strip printer, along with the channel number to indicate gage locations.

\section{System Fail Proofing}

As may be noted from the system drawings (Appendix G), there is duplication of circuit functions. This duplication was planned in order to provide methods for continued monitoring of strain should there be a loss of components or whole circuit cards after installation was complete. With four channels per card, a card loss would result in a loss of only one sixth of capability. The multiplexer card is duplicated so that a loss of a 


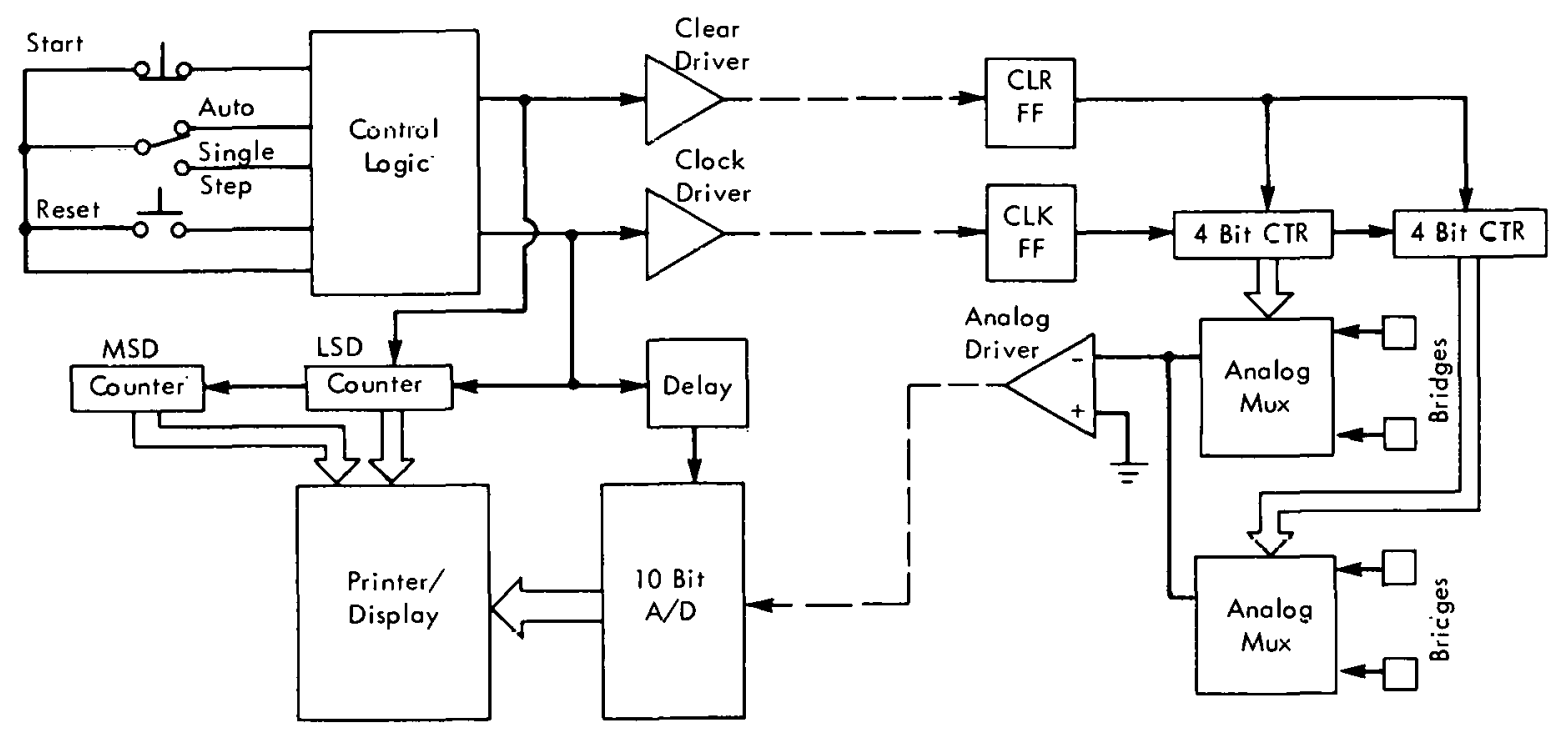

Figure 4. STRAIN MONITOR SYSTEM.

multiplexer would not destroy the system's functions. The multiplexer outputs are supplied on two output lines so that loss of a lead during installation would not destroy the system's furction. As the gages were connected to the bridges, a careful selection was made so that loss of a gage, an amplifier, or a multiplexer would not mean loss of data from a particular area on the thread root. A final attempt to prevent system failure from causing loss of all data was to extend leads from five of the active gages, plus two reference gages, through the bleeder holes, thus providing for manual measurement.

\section{Debugging}

The entire system was fabricated in the Y-12 Electroniss Fahriration Shop, with fixed resistors as dummy gages and lead wire for each channel. The system was tested and calibrated to the dummy resistors to duplicate expected on-site operation. The amplifiers for each channel were tested for output linearity and span. Those amplifiers that were marginal or intermittent were replaced and that channel retested.

\section{Burn In}

Completion of the debugging stage left the system with all channels in operation at or near the design standards. The system was then put through a burn-in cycle of two weeks to detect any malfunctioning components during continuous operation. This test was deemed to be necessary since the system, once installed, would he anproximately $90 \%$ inaccessiblu. Only two channels failed during this period and were left in an inoperative condition since several of the installed gages would be monitored with a manual backup.

\section{SITE PREPARATION}

)

\section{Cleaning}

Site preparation of the vessel for installation of the gages and instrumentation was extensive. Previously installed gages were removed and the thread roots examined by ultrasonic and 
dye-penetrant inspection techniques. To perform these inspections, the thread roots were ground and honed to remove rust, scale, and small voids, seen in Figure 5.

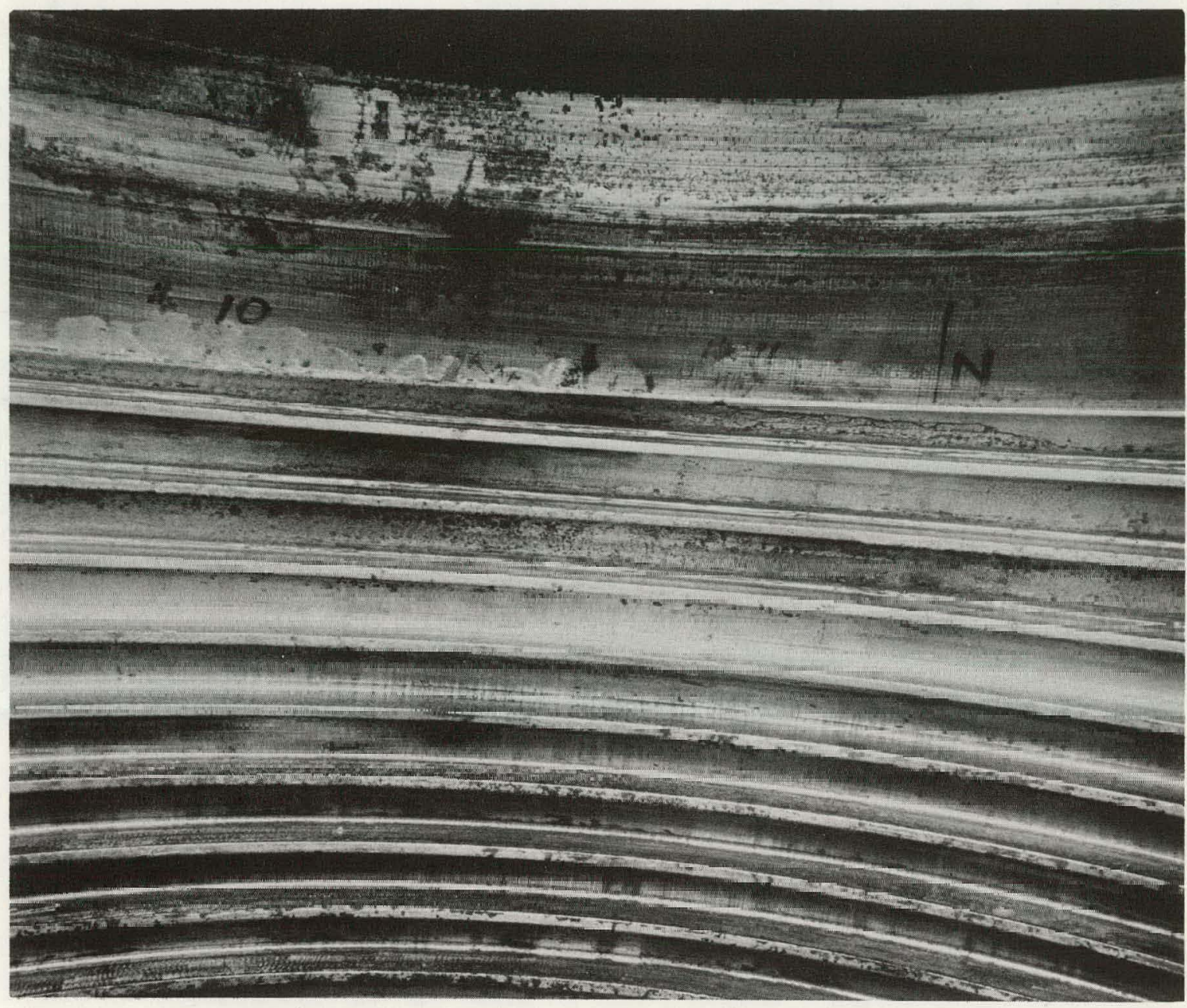

156491

Figure 5. THREAD ROOTS, SHOWING RUST, SCALE, AND SMALL VOIDS.

\section{Ultrasonic Inspection}

Ultrasonic inspection used the contact-testing, pulse-echo method. The lower ID and plug threads were tested using a 5-MHz, Aerotech Miniature, transducer with an 80-degree plastic shoe that produced a shear wave in the threads. A standard ultrasonic model (Figures 6 and 7), with Elox slots of different dimensions, was used to calibrate the ultrasonic instrument. The first four threads were inspected. There was no indication of flaws observed during the inspection.

\section{Dye-Penetrant Inspection}

The first dye-penetrant inspection used Spotcheck Cleaner (SKC-5) as the solvent with penetrant (ZL-2) and developer (ZP-9), which is a nonaqueous wet developer. There were no 


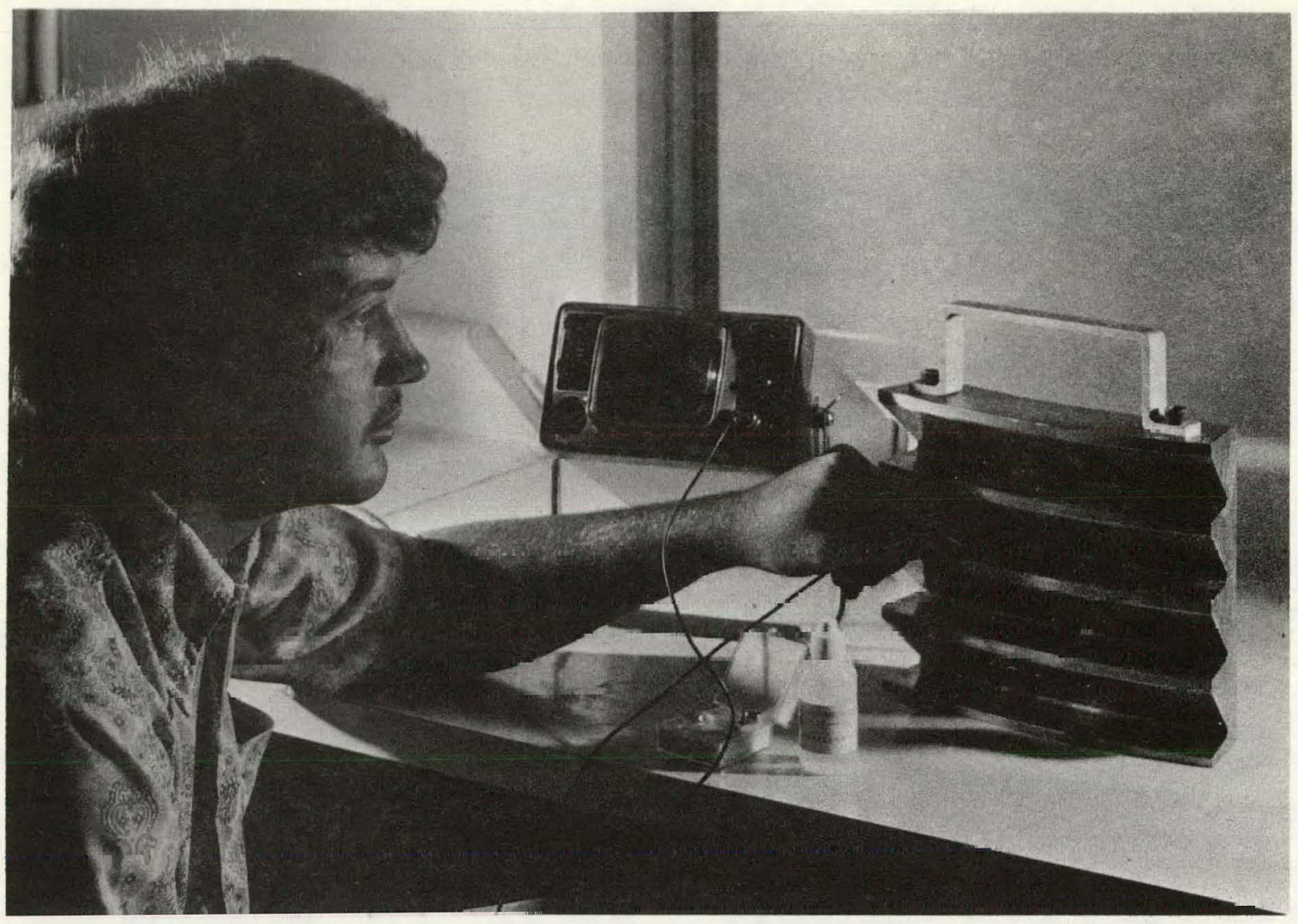

Figure 6. STANDARD THREADS USED TO CALIBRATE THE ULTRASONIC INSTRUMENT.

155672

cracks detected. However, there was considerable rust and pitting. There was a high amount of background fluorescence, making evaluation difficult.

The second inspection, performed after grinding and hnning of the first four threads, as scon in Figure 5, differed only through the use of ZL-30A penetrant. There were no detectable cracks.

It should be noted that only the first four threads were inspected, based on statements by the stress analysts that this area is that which would result in catastrophic failure should cracking occur.

\section{SYSTEM INSTALLATION}

\section{Gage}

The gages were located in pairs due to the results received from gages previously installed. The gage pairs were located, as indicated in Figure 8, as follows: first thread - five pairs, second thread - three pairs, and third thread - two pairs. A pair of temperature and zero stress reference gages mounted on a steel block were located in the area near the printed circuit cards. Additionally, a pair of gages, which had been prestressed to approximately $2500 \mu \mathrm{m} /$ in were mounted on a steel block, and also located in the same area. These gages were installed to provide data on temperature compensation for the system. 


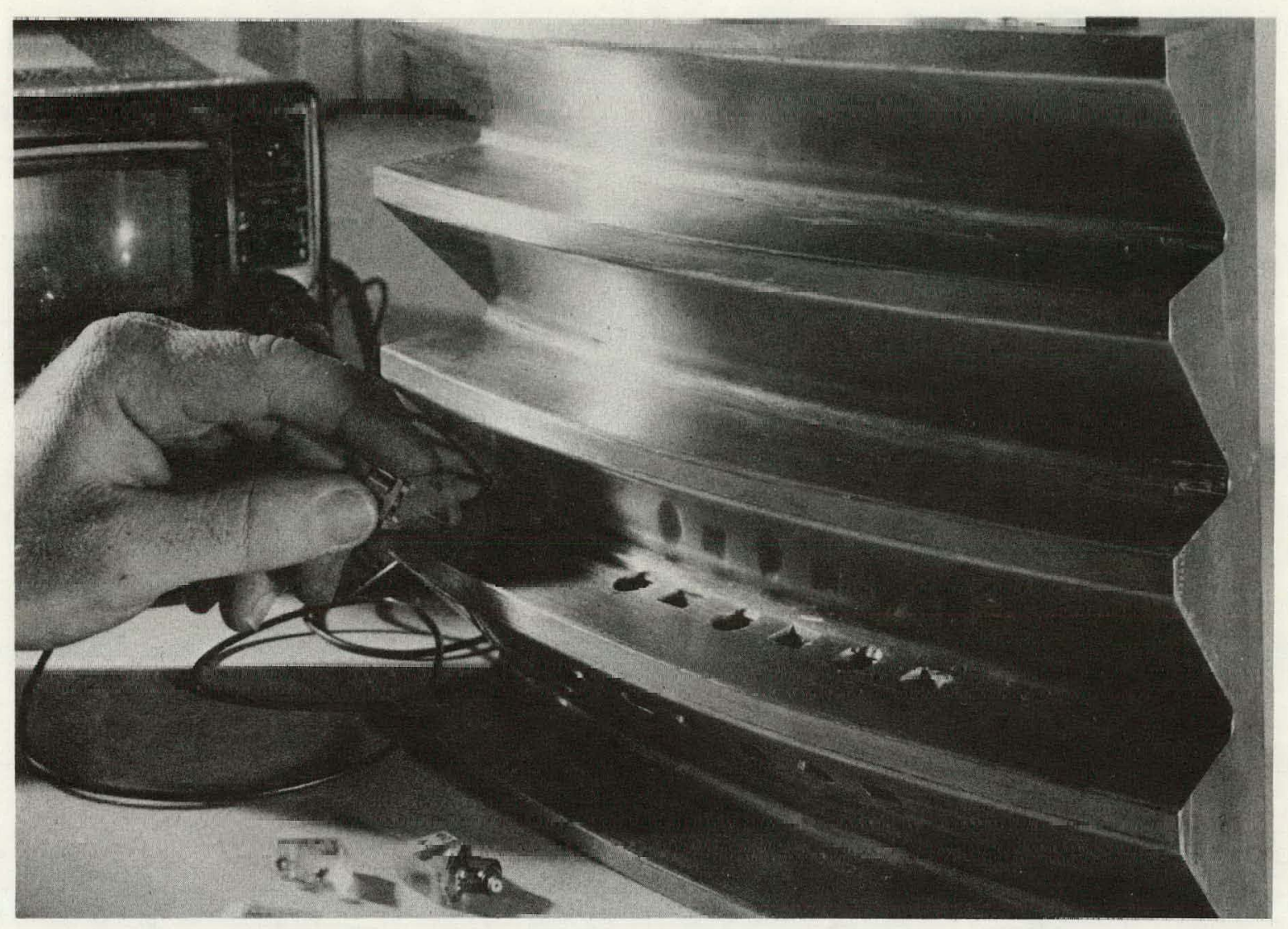

Figure 7. CLOSEUP VIEW OF THE STANDARD-THREAD ASSEMBLY.

155673

Each gage location was further polished with emery cloth and passivated with metal conditioner and neutralizer. A catalyst was applied to the gage back and Eastman 910 cement to the attachment surface. Terminal tabs were similarly located at each gage site for attaching the gage and lead wires. A total of 24 gages (Micro-Measurements, Type EA-06-050SB-120) were mounted in the lower portion of the vessel. The gage resistance was $120.0 \pm 0.3 \%$ ohms with a gage factor of $1.99 \pm 1.0 \%$.

Twenty of the gages were installed in the root of the top three threads of the lower ID of the vessel. The gages were mounted in pairs at ten different locations, as noted in Figure 8. The remaining four gages were mounted in pairs to two compensator blocks. These compensator blocks were then mounted to the wall of the vessel above the threaded area.

\section{Lead Wire}

The lead wire from each pair of gage-terminal tabs was cut to 38 feet 9 inches. The lead wires of size 34 gage enamel wire, were cemented with Eastman 910 to the thread root at intervals of approximately six inches. The excess lead wire from the nearest gages was coiled and bonded to the surface of the vessel above the threaded area. The free ends of the lead were attached, by soldering, to a barrier strip (Cinch Jones, Type 141-10). Each gage-and-lead wire installation was completed by applying two coats of Gage Kote 2 and then applying two coats of Gage Kote 5 for waterproofing. Typical completed gage-and-lead wire installations can be seen in Figure 9. 

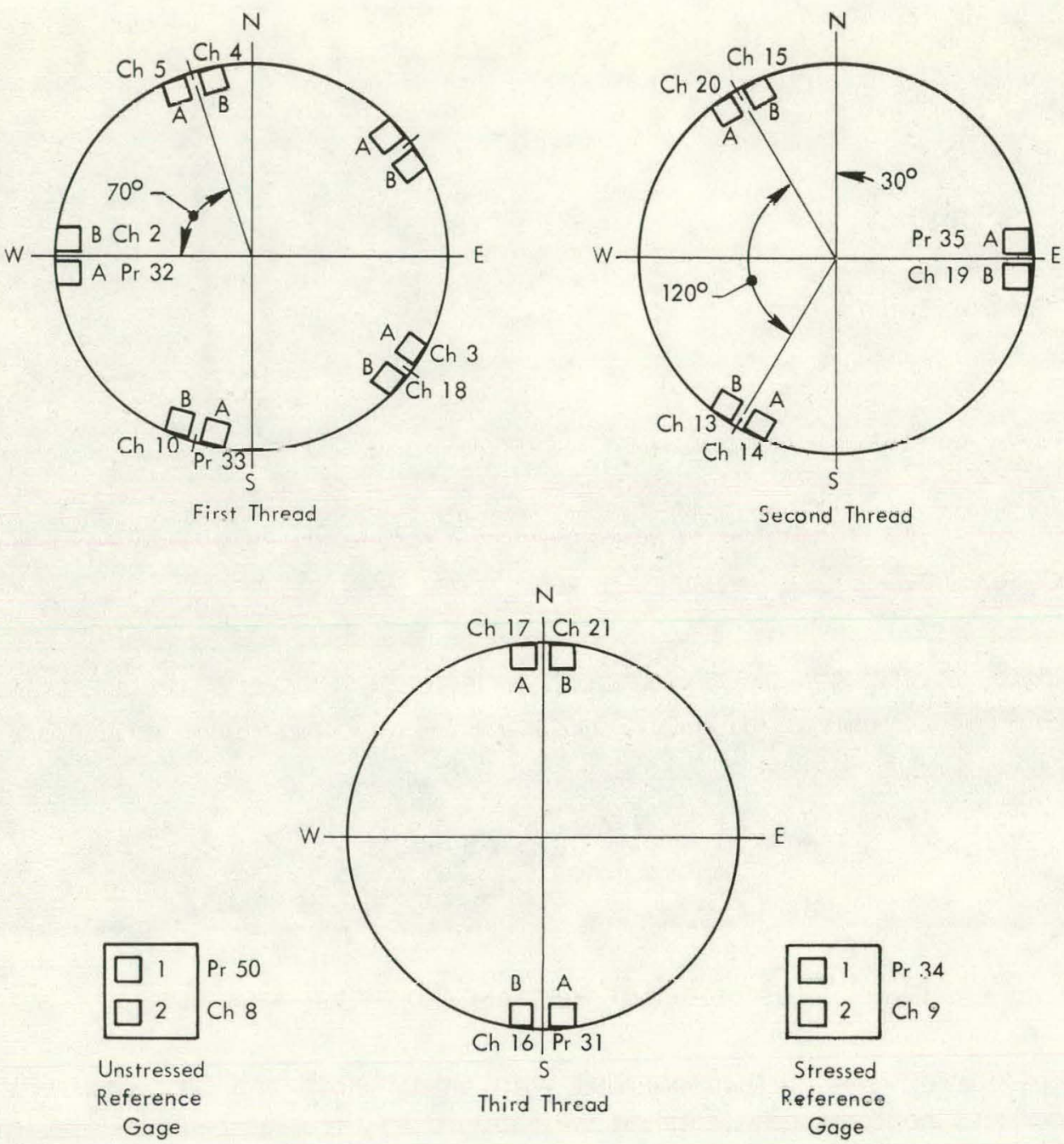

Figure 8. LOCATIONS OF GAGE PAIRS. (View is from the Top of PV-2 Downward: Ch Indirates Channel of the Strain Monitor System; Pr Indicates Wire Pair of the Manual System)

Resistance readings of each gage and associated lead wires were taken after installation. These resistances are listed in Tables 1 and 2 .

\section{Electronics}

System electronics were installed in three sections. The control console, as seen in Figure 10 , was located in the control room, approximately 200 feet from the pressure vessel, with the PV-2 control console. The power supply, as viewed in Figure 11, for the bridge/amplifier and multiplexer cards was located on the lower support base for the pressure vessel. The bridge/amplifier and multiplexer cards were located in the free volume of the pressure vessel closure, pictured in Figure 12.

The circuit cards and barrier strips were mounted on standoff pads of Micarta, indicated in Figure 13. Power and signal lines were brought from the barrier strips to the power supply and control console through bleeder holes in the pressure vessel bottom plug, as Figure 14 reveals. 


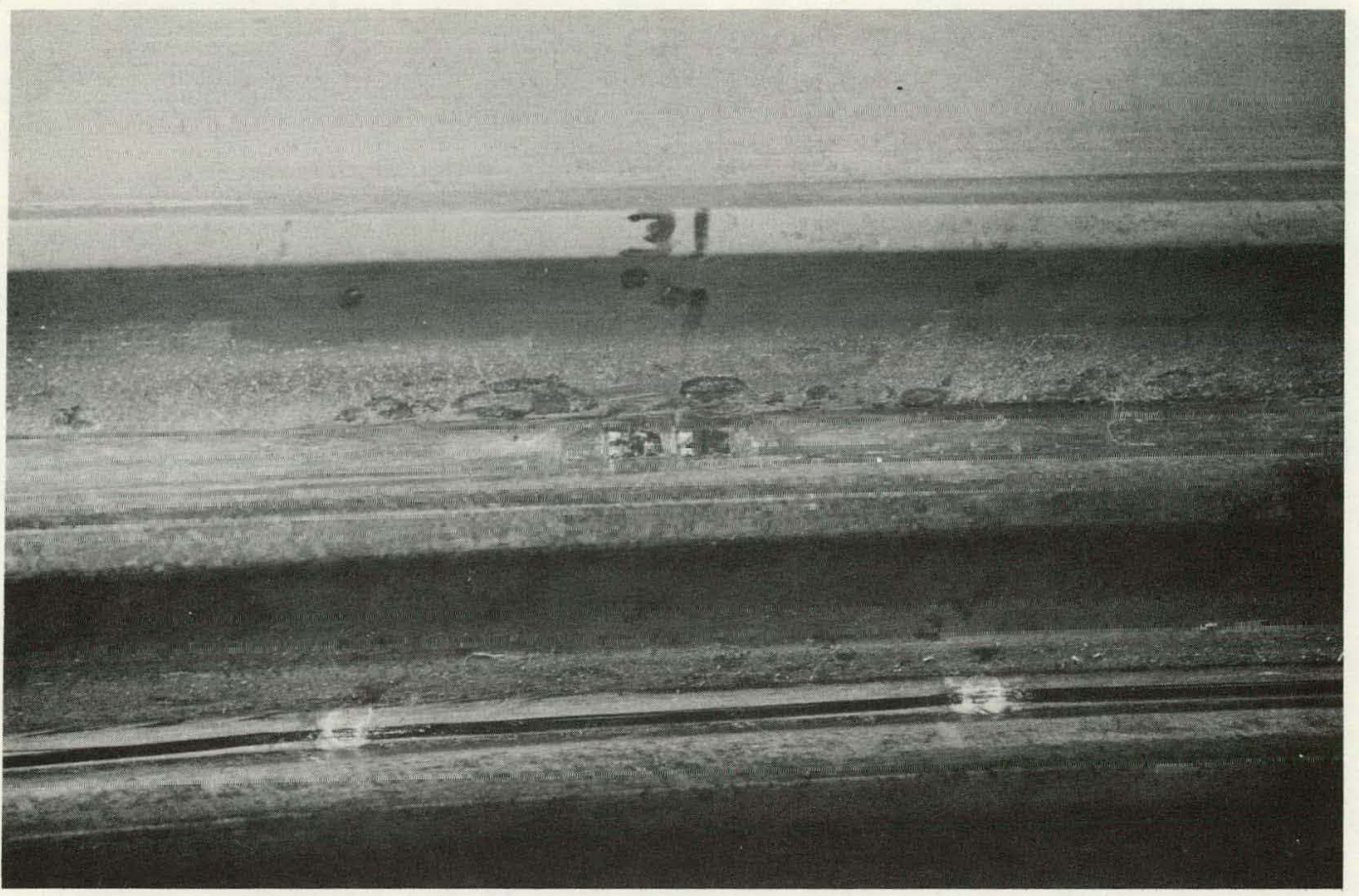

(a) View 1.

155674

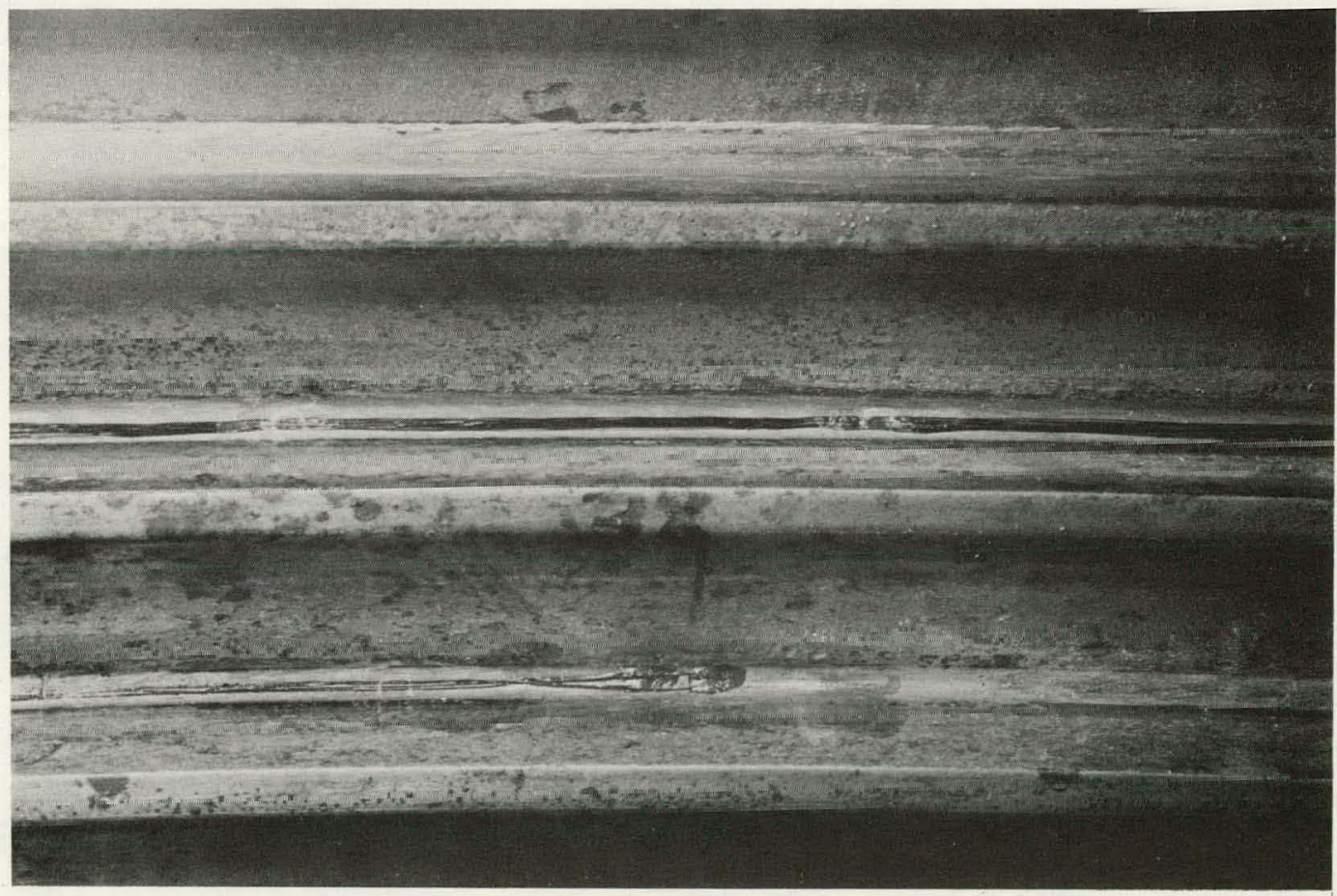

(b) View 2.

155675

Figure 9. TYPICAL GAGE AND LEAD WIRE INSTALLATIONS. 
Table 1

SY'STEM CALIBRATION DATA

\begin{tabular}{|c|c|c|c|c|c|}
\hline \multicolumn{6}{|c|}{$\begin{array}{l}\text { Shunt Resistance }=100000 \\
\text { Gage Factor }=1.99 \\
\text { Gage Resistance }=120\end{array}$} \\
\hline $\begin{array}{l}\text { Channel } \\
\text { Number }\end{array}$ & $\begin{array}{l}\text { Measured } \\
\text { Resistance }\end{array}$ & $\begin{array}{l}\text { Gage } \\
\text { Factor }\end{array}$ & Micros-rain & $\begin{array}{l}\text { Delta } \\
\text { Volts }\end{array}$ & $\begin{array}{c}\text { Microstrain } \\
\text { Per Volt }\end{array}$ \\
\hline 2 & 141.9 & 1.6829 & $842.0 \supset 49$ & 1.6200 & 519.7561 \\
\hline 5 & 141.5 & 1.6876 & 837.2579 & 1.5800 & 529.9164 \\
\hline 4 & 141.9 & 1.6829 & $842.0 \supset 49$ & 1.7100 & 492.4006 \\
\hline 7 & 141.9 & 1.6829 & $842.0 \supset 49$ & 1.5700 & 536.3089 \\
\hline 3 & 142.3 & 1.678 & 846.7553 & 1.6700 & 507.0391 \\
\hline 18 & 141.9 & 1.6829 & 842.0549 & 1.6300 & 516.5675 \\
\hline 10 & 141.8 & $1.684 I$ & 840.8194 & 1.6400 & 512.6948 \\
\hline 20 & 142.1 & 1.6805 & 844.3785 & 1.6100 & 524.4587 \\
\hline 15 & 141.8 & 1.6841 & 840.8194 & 1.6300 & 515.8402 \\
\hline 19 & 141.8 & 1.6841 & 840.8194 & 1.5500 & 542.4642 \\
\hline 14 & 141.8 & 1.6841 & 840.8194 & 1.6300 & 515.8402 \\
\hline 13 & 141.7 & 1.5853 & 839.6348 & 1.6400 & 511.9724 \\
\hline 17 & 141.7 & 1.5853 & 839.6348 & 1.6100 & 521.5123 \\
\hline 21 & 141.8 & 1.5841 & 840.8194 & $1.670 \mathrm{C}$ & 503.4847 \\
\hline 16 & 141.6 & 1.5864 & 838.4509 & $1.640 \mathrm{C}$ & 511.2506 \\
\hline 9 & 141.7 & 1. 3853 & 839.6348 & $1.630 \mathrm{C}$ & 515.1134 \\
\hline 8 & 141.7 & 1. 3853 & 839.6348 & $1.530 \mathrm{C}$ & 548.7809 \\
\hline
\end{tabular}

Table 2

MANUAL GAGE CALIBRATION DATA

(Gage Factor for Manual Gages)

\begin{tabular}{ccc}
\hline $\begin{array}{c}\text { Manual } \\
\text { Gage Number }\end{array}$ & $\begin{array}{c}\text { Measured } \\
\text { Resistance } \\
\text { (ohms) }\end{array}$ & $\begin{array}{c}\text { Gage } \\
\text { Factor }\end{array}$ \\
\hline 31 & 153.11 & 1.5597 \\
32 & 153.40 & 1.5567 \\
33 & 153.03 & 1.5605 \\
34 & 152.73 & 1.5635 \\
35 & 153.30 & 1.5577 \\
36 & 153.70 & 1.5537 \\
Ref. & 152.83 & \\
\hline
\end{tabular}



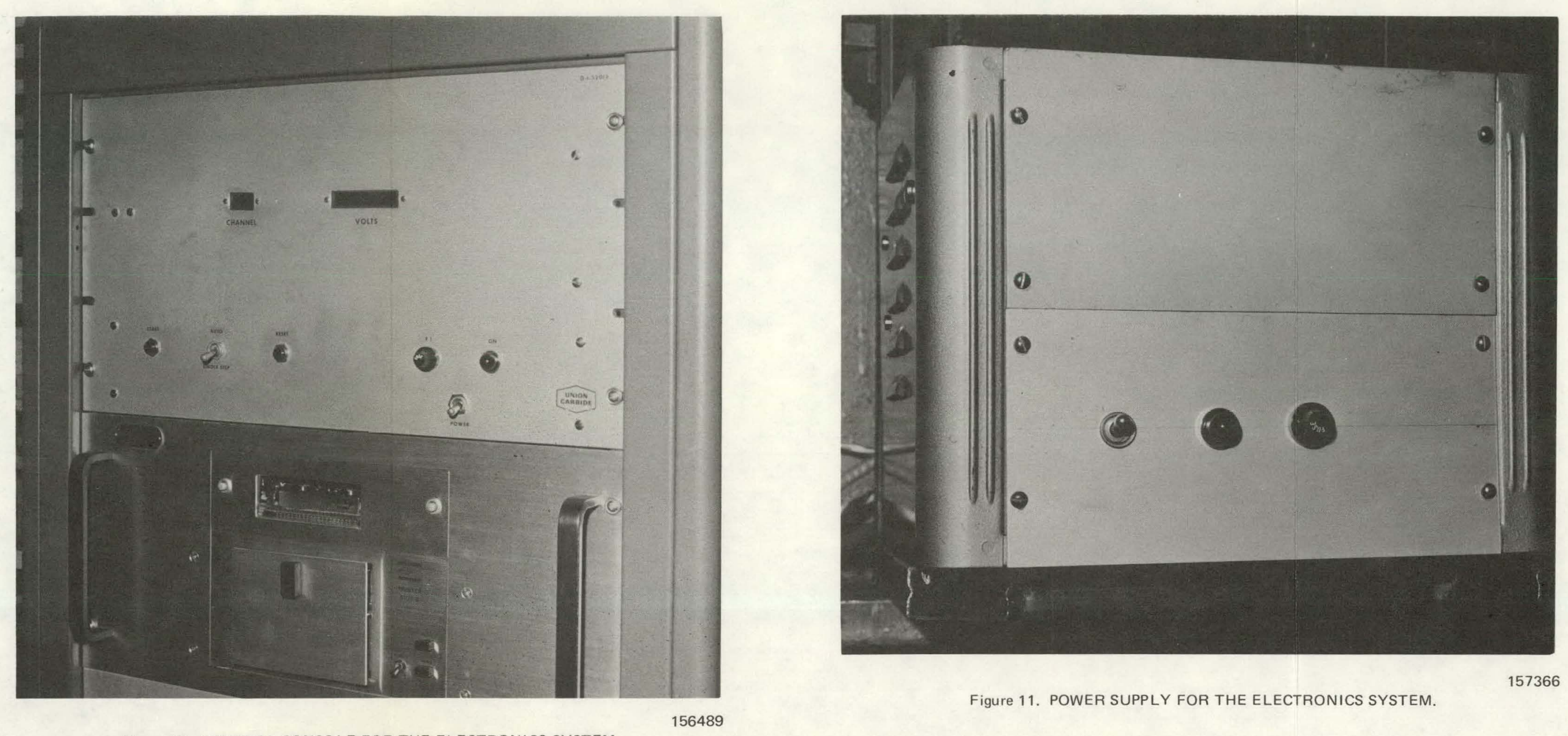

Figure 10. CONTROL CONSOLE FOR THE ELECTRONICS SYSTEM.
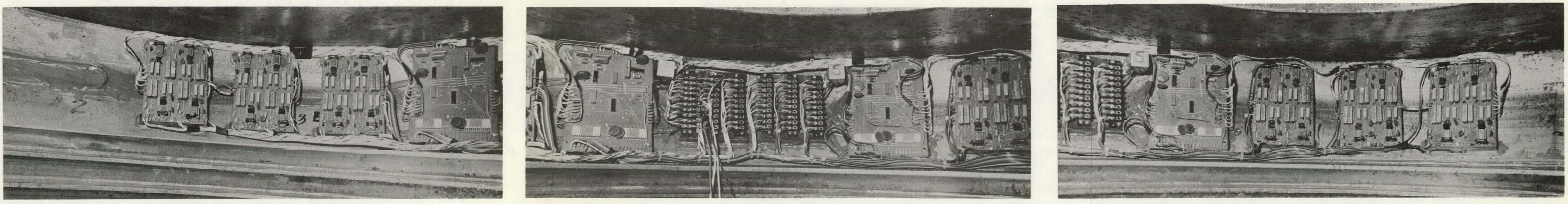


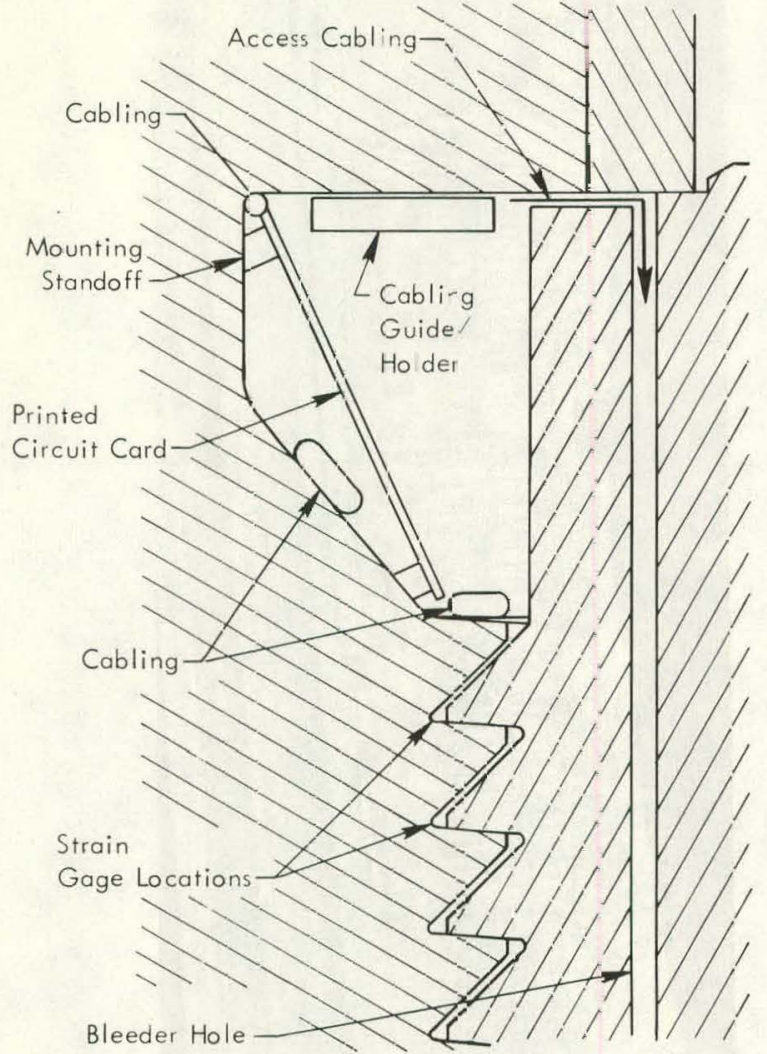

Figure 13. METHOJ AND LOCAT ON FOR MOUNTING THE CIRCUIT CARDS AND BARR ER STRIPS.

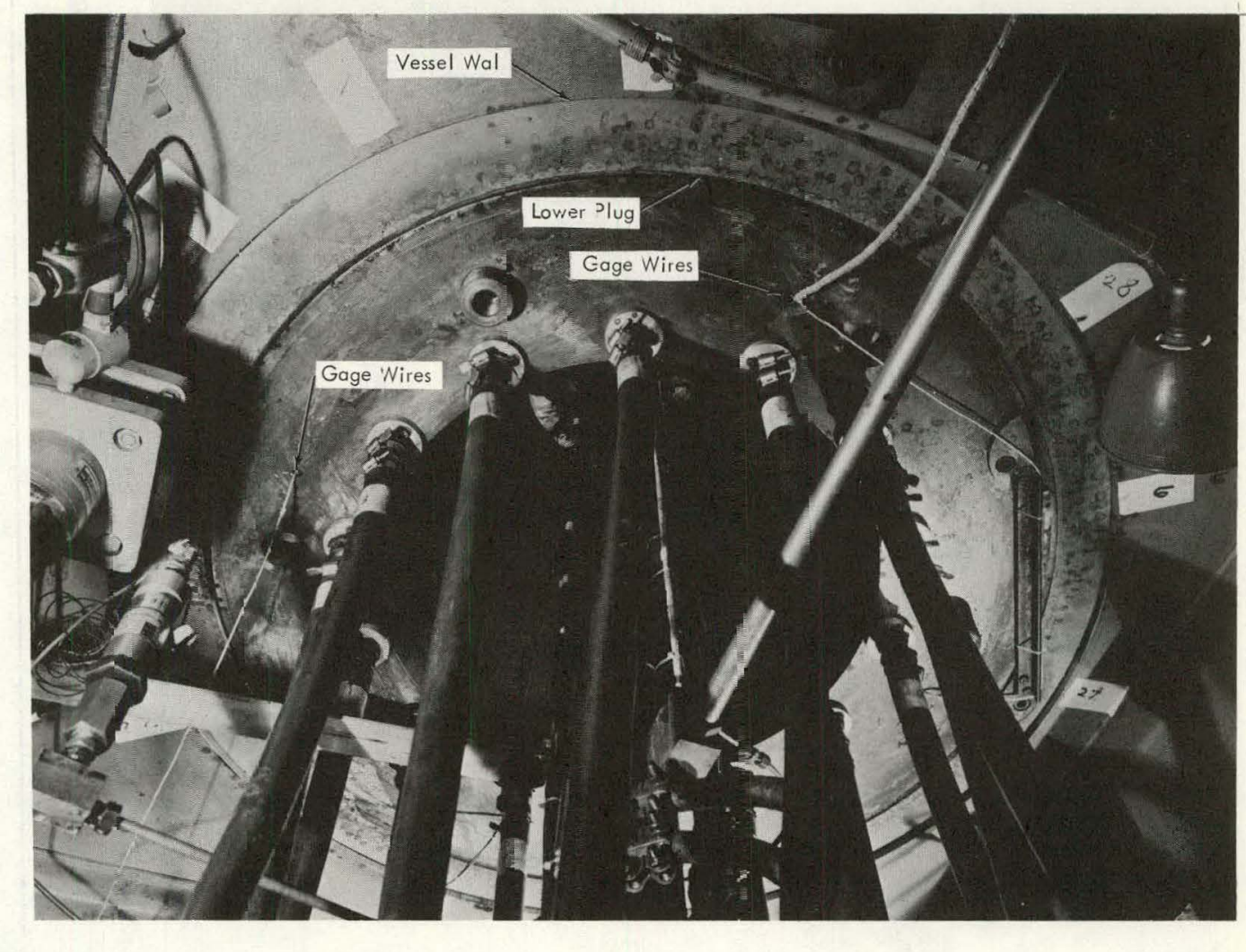

Figure 14. BOTTOM FEEDTHROUGHS FOR THE PRESSURE VESSEL. 


\section{Calibration}

Each gage-and-lead wire pair were connected to a bridge circuit and the output placed near zero. A fixed resistor was used to shunt the gage to simulate the midrange compression strain. An output voltage was obtained for future use as a span factor when calculating strain. Before final vessel closure, this process was checked several times to check drift of the various channels. No appreciable drift was noticed.

\section{CALCULATIONS FOR INSTRUMENTATION}

The gage factor (GF) is defined as: (2)

$$
\mathrm{GF}_{\text {gage }}=\frac{\Delta R / R}{\Delta \mathrm{L} / \mathrm{L}}
$$

where:

$\Delta R$ represents the change in resistance,

$R$ the gage resistance,

$\Delta \mathrm{L}$ the change in gage length, and

$L \quad$ the gage length.

Similarly, for an installation having a lead resistance, $R_{L}$, a gage factor may be defined as:

$$
G F_{\text {new }}=\frac{\Delta R / R_{g}+R_{L}}{\Delta L / L}
$$

where:

$\Delta \bar{R}$ represents the change in resistance,

$\mathrm{Rg}_{\mathrm{g}}$ the gage resistance,

$R_{L}$ the line resistance,

$\Delta \mathrm{L}$ thc change in gage length, and

$L \quad$ the gage length.

Solving for $\frac{\Delta L}{L}$ in Equation 1 yields:

$$
\frac{\Delta \mathrm{L}}{\mathrm{L}}=\frac{\Delta \mathrm{R} / \mathrm{R}_{\mathrm{g}}}{\mathrm{G} \mathrm{F}_{\text {gage }}} .
$$


By substitution in Equation 2:

$$
G F_{\text {new }}=\frac{R_{g}}{R_{g}+R_{L}} G F_{\text {gage }}
$$

Since the measured resistance, $R_{m}$, after installation was known, the equation may be rewritten as:

$$
G F_{\text {new }}=\frac{R_{g}}{R_{m}} G F_{\text {true }}
$$

The standard strabin equatıon tor any gage is:

$$
\frac{\Delta \mathrm{R}}{\mathrm{R}_{\mathrm{g}}}=\mathrm{G} \mathrm{F}_{\text {true }} \frac{\Delta \mathrm{L}}{\mathrm{L}} .
$$

With a compensating Gage Factor, this expression becomes:

$$
\frac{\Delta R}{R_{g}}=G F_{\text {new }} \frac{\wedge I}{L} .
$$

The expression can now be written:

$$
\frac{\Delta \mathrm{L}}{\mathrm{L}}=\frac{\Delta \mathrm{R}}{\mathrm{R}_{\mathrm{g}}} \frac{1}{\mathrm{GF} \text { new }}
$$

which resolves to:

$$
\frac{\Delta L}{L}=\frac{\Delta R}{R_{g}} \frac{R_{m}}{R_{g} G F_{\text {true }}} .
$$

To calibrate the instrumentation, a shunt resistor of 100,000 ohms was placed across $R_{m}$ to simulate a $\Delta R$ where:

$$
\frac{\Delta L}{L}=\frac{\frac{\left(R_{m}\right)(100,000)}{100,000+R_{m}}}{R_{g}} \frac{R_{m}}{R_{g} G F_{\text {true }}}
$$

Application of the shunt resulted in a change in voltage, $\Delta V$, at the instrumentation output. A program was prepared for the HP 9830, a programmable desk-top calculator, to determine the $G F_{\text {new }} \frac{\Delta L}{L}$, and $\frac{\Delta L}{L}$ per volt. The program is given in Appendix $A$ and the program data 
generated are shown in Table 1. These data are used as a calculation factor and applied to the readings taken during a pressure run of $\mathrm{PV}-2$.

A program was prepared for the HP 9830 to reduce the data from a pressure run. This program determines the change in voltage and.converts this change to microstrain. A copy of the program is given in Appendix B. Appendix $C$ is a copy of a file output program.

\section{RESULTS}

Due to the large volume of data available from the system, the HP 9830 programmable calculator was programmed to analyze the resulting data and format the output for easy interpretation. Appendixes $A$ through $C$ contain programs to determine calibration data, strain conversion, and the file output programs, respectively. Sample data received from the system are contained in Appendix D.

Appendix $E$ contains a program prepared to provide graphical comparisons, as shown in Appendix D, of the system data and data received from the pressure vessel in 1964. The graphical comparisons comprise Appendix $F$ of this report. These data are duplicated in Table 3 for comparison purposes.

Stress analysis of the vessel is contained in a separate report. (3)

Engineering drawings of the strain gage system are contained in Appendix G.

Table 3

COMPARISON OF RECENT DATA WITH EARLIER DATA

\begin{tabular}{|c|c|c|c|c|c|c|c|c|c|c|c|}
\hline \multirow{3}{*}{$\begin{array}{c}\text { Channel/ } \\
\text { Gage } \\
\text { Number }\end{array}$} & \multicolumn{7}{|c|}{1974 Data } & \multicolumn{4}{|c|}{1964 Data } \\
\hline & \multicolumn{7}{|c|}{ Pressure (psi) } & & & & \\
\hline & 0 & 5000 & 10000 & 15000 & $15000^{(1)}$ & $10000^{(1)}$ & $5000^{(1)}$ & 0 & 5000 & 10000 & 15000 \\
\hline 2 & 0 & 104 & 423 & 755 & 764 & 548 & 166 & 0 & 248 & 466 & 714 \\
\hline 32 & 0 & 322 & 652 & 869 & 869 & 706 & 309 & 0 & & & \\
\hline 5 & 0 & 1081 & 1777 & 2423 & 2297 & 1937 & 1270 & 0 & 852 & 1487 & 2086 \\
\hline 4 & 0 & 318 & 1533 & 2100 & 2071 & 1715 & 1170 & 0 & & & \\
\hline 7 & 0 & 257 & 695 & 1199 & 1171 & 764 & 278 & 0 & 525 & 1061 & 1675 \\
\hline 36 & 0 & 202 & 623 & 1070 & 1070 & 706 & 233 & 0 & & & \\
\hline 3 & $\mathbf{0}$ & 314 & 657 & 955 & 931 & 669 & 298 & 0 & 585 & 1120 & 1774 \\
\hline 18 & 0 & 522 & 1104 & 1651 & 1613 & 1157 & $542^{(2)}$ & & & & \\
\hline 10 & 0 & 672 & 1094 & 1485 & 1474 & 1220 & 798 & 0 & 981. & 1388 & 1804 \\
\hline 33 & 0 & 437 & 758 & 956 & 956 & 788 & 505 & 0 & & & \\
\hline 20 & 0 & -339 & -336 & -198 & -189 & -258 & -280 & 0 & -119 & 59 & 357 \\
\hline 15 & $\mathbf{0}$ & -265 & -204 & 22 & 72 & -91 & -163 & $\mathbf{0}$ & & & \\
\hline 19 & 0 & 638 & 855 & 1047 & 1013 & 949 & 745 & 0 & 615 & 852 & 1100 \\
\hline 35 & 0 & 500 & 600 & 710 & 710 & 692 & 575 & 0 & & & \\
\hline 14 & 0 & -188 & -75 & 36 & 33 & -57 & -191 & 0 & 506 & 525 & 615 \\
\hline 13 & 0 & -309 & -258 & -209 & -222 & -255 & -317 & 0 & & & \\
\hline 17 & 0 & 403 & 506 & 595 & 575 & 522 & 415 & 0 & 466 & 783 & 1080 \\
\hline 21 & 0 & 424 & 606 & 776 & 769 & 657 & 459 & 0 & & & \\
\hline 16 & 0 & 353 & 563 & 733 & 752 & 651 & 430 & 0 & 347 & 595 & 857 \\
\hline 31 & 0 & 334 & 543 & 625 & 625 & 564 & 371 & 0 & & & \\
\hline
\end{tabular}

(1) Vessel pressure was hịher than indicated dụe to location of the pressure sensor.

(2) No sensitivity. 


\section{CONCLUSIONS AND RECOMMENDATIONS}

Data received from the system compares favorably with that obtained manually in 1964 in both magnitude and direction of strains occurring during pressure vessel operation.

The system provides data in a repeatable fashion and with much greater ease than previously obtainable. Additionally, data may be obtained on each run, if desired, rather than once each year as was previously done, using a special equipment setup and requiring coordination between operating groups.

Worthy of special note is the detection by the system of the existence of a pressure differential between the actual vessel pressure and the pressure as indicated by the normal PV-2 monitoring equipment. This condition was corrected by relocation of the pressure transducer trom the inlet lines of the vessel to a point as near the vessel as practical for better control of vessel pressure.

Where feasible, a system such as that described in this report should be installed on operating pressure vessels to provide operating data rather than static data as a means of observing strains in such vessels. Observation and historical data obtained in this manner will allow detection of potential failures long before actual failure occurs. 


\section{REFERENCES}

(1) Long, P. J. and Ross, W. D.; Strain Gage Test at the Threaded Closure on a Thirty-Inch Pressure Vessel Y-1471; Union Carbide Corporation-Nuclear Division, Oak Ridge Y-12 Plant, Oak Ridge, Tennessee; November 20, 1974.

(2) Perry, C. C. and Lissner, H. R.; The Strain Gage Primer, Second Edition, pp 18-30, 55-73; McGraw-Hill Book Company, Inc, New York, N. Y.

(3) Pohto, H. A.; Brittle Failure of a Large High-Pressure Isostat and a Comparison Analysis of Its Twin Vessel, Y-1989; Union Carbide Corporation-Nuclear Division, Oak Ridge Y-12 Plant, Oak Ridge, Tennessee; August 20, 1975. 


\section{ACKNOWLEDGEMENTS}

The authors wish to express their thanks for the assistance and cooperation provided by W. D. Ross, Physical Testing; J. McDonald and D. Manovich, Y-12 Maintenance, and R. M. Jones, Physical Testing. 


\section{APPENDIX A}

\section{PROGRAM TO CALCULATE SYSTEM CALIBRATION DATA (Output Shown in Table 1)}

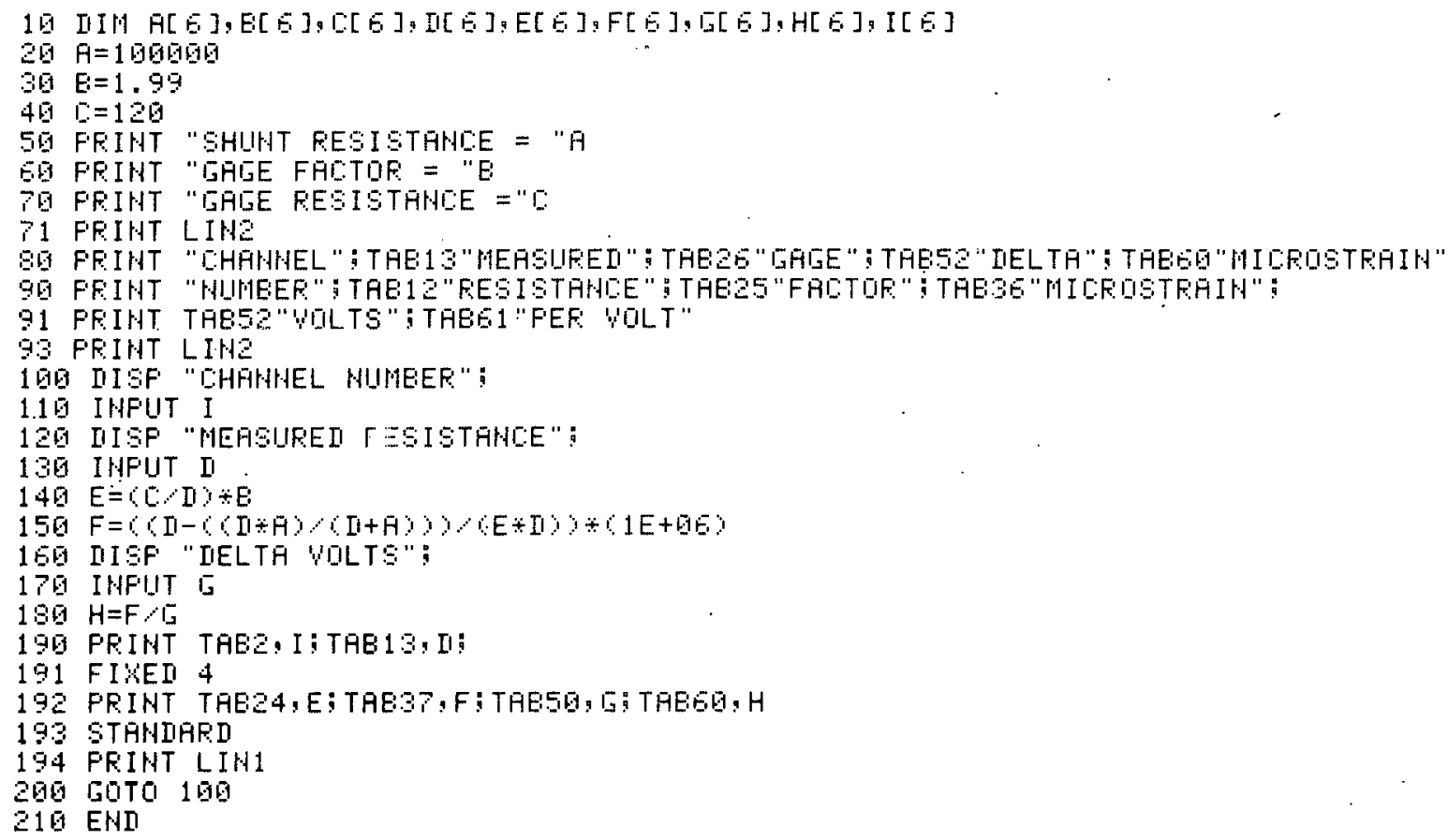




\section{APPENDIX B}

\section{PROGRAM TO CONVERT SYSTEM OUTPUT TO STRAIN DATA (Example in Appendix}

C)

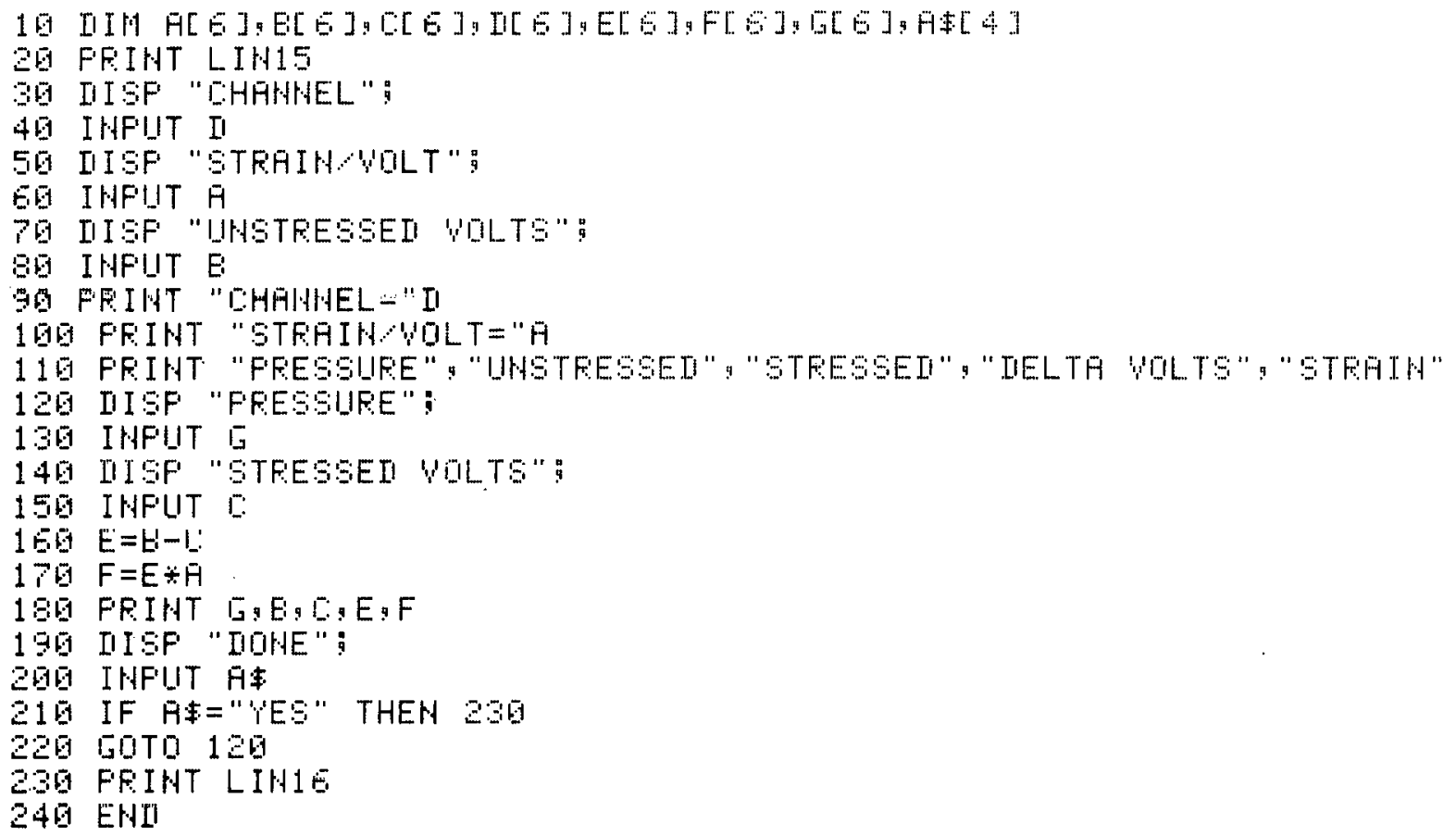




\section{APPENDIX C}

\section{PROGRAM TO OUTPUT DATA FILE FROM THE PREVIOUS TEST (Output Same as Appendix D)}

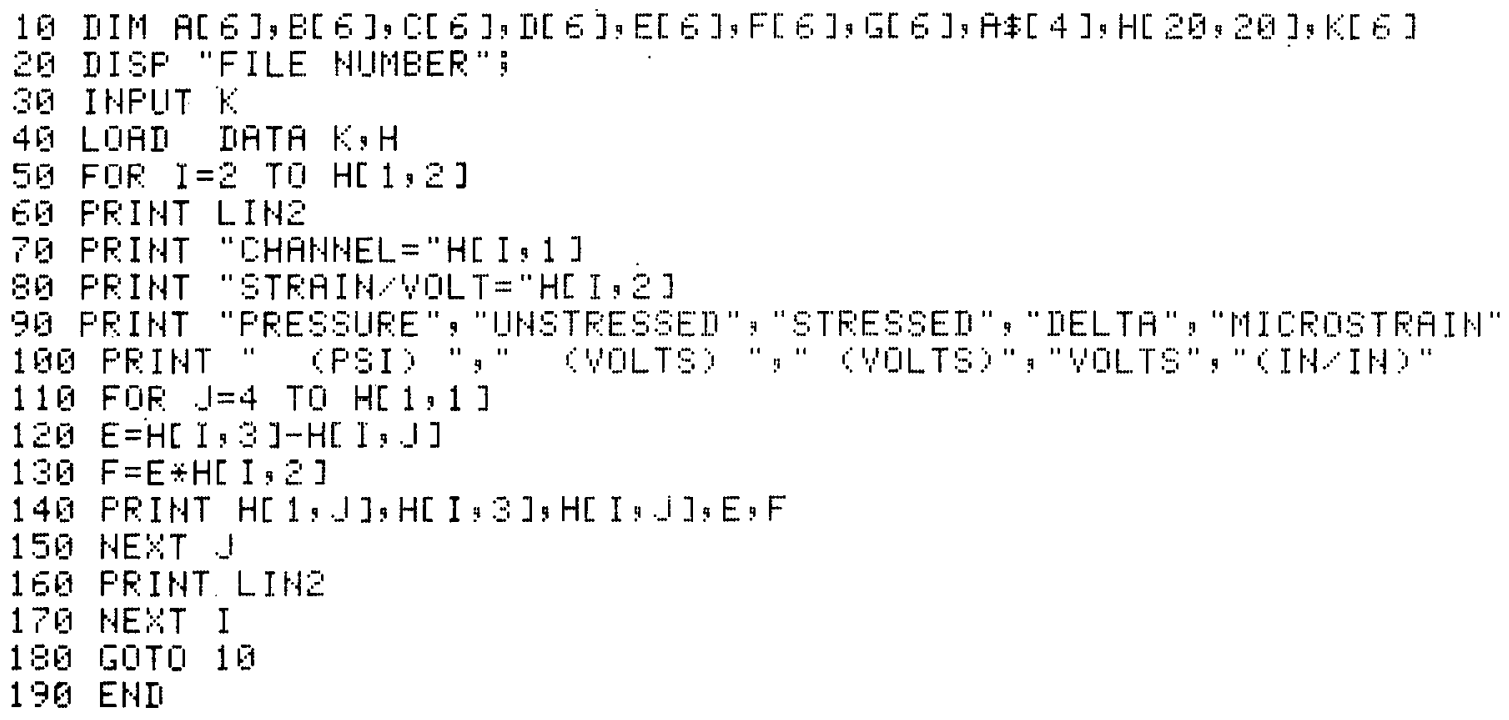




\section{APPENDIX D}

\section{SAMPLE STRAIN DATA}

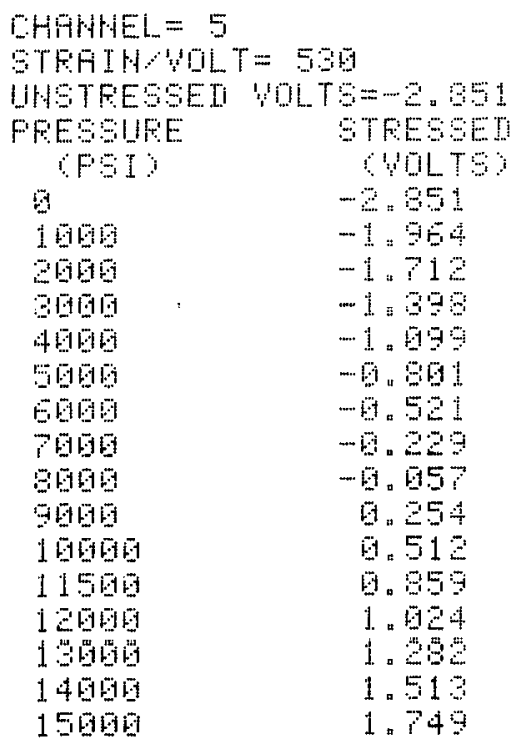

CHAHHEL $=4$ STFIIH UOLT $=492$ IHSTEESEEI WOLTE=-4.40L

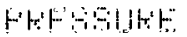

\begin{tabular}{|c|c|}
\hline \multicolumn{2}{|r|}{ U⿴LTT: } \\
\hline 6 & -4.461 \\
\hline 1000 & $-3+27$ \\
\hline $\begin{array}{l}2060 \\
3696\end{array}$ & -3.09 \\
\hline 4 कीज & $-3 \times 99$ \\
\hline 5000 & $-2,59$ \\
\hline 6060 & -2.26 \\
\hline 7190 & -1.955 \\
\hline 8601 & -1.714 \\
\hline Y4t6b & $-1,5$ \\
\hline 16000 & -1.270 \\
\hline 115019 & -6.94 \\
\hline 12000 & -0.785 \\
\hline 13006 & -0.535 \\
\hline & $-6,3$ \\
\hline & \\
\hline
\end{tabular}

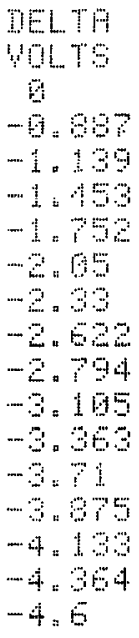

MICFOSTFAIH IIH I H Q

$-470.11$

$-603.6 ?$

$-79.90$

$-928.56$

$-10965$

$-1234.9$

$-1389.66$

$-1489,82$

$-1645,65$

$-1782,99$

$-1965.3$

$-2105,75$

$-2190.49$

$-232.92$

$-245$
MILEOETEAIH

It I IO

a

$-454.671$

$-597,631$

$705 \cdot 149$

$-924.168$

$-1191.01$

$-1232.704$

$-1367.464$

$-1478.675$

$-1542.356$

$-1777.449$

$-15 y .12$

$-2947.162$

$-2191.765$

$-2301.391$

$-2423.177$

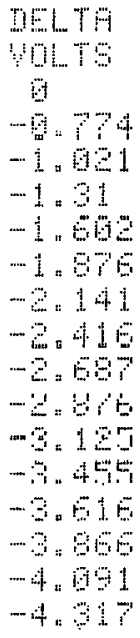

$$
\begin{aligned}
& \text { MICFin' } \\
& \text { I I I I S } \\
& 9 \\
& -380,869 \\
& -562.33 \\
& -644.52 \\
& -788.184 \\
& -922.992 \\
& -1053,92 \\
& \text { - } 11 \% \text { क } 7 \% \\
& -1922 \text {. } \\
& -141.455 \\
& -1537,5 \\
& -1699.86 \\
& -1779.672 \\
& -1902.672 \\
& \text { - } 2612.772 \\
& -2123.964
\end{aligned}
$$


EHAHAHEL $=\vec{i}$

STFHIHUILT = 53

DHSTFEGEE WDLTS=-2. ETP

\begin{tabular}{|c|c|c|}
\hline $\begin{array}{c}\text { FFEGUIIFE } \\
\text { FII }\end{array}$ & $\begin{array}{r}\text { OTFESSED } \\
\text { YULTE }\end{array}$ & $\begin{array}{l}\text { DELTH } \\
\text { WILTES }\end{array}$ \\
\hline 1 & $-\Xi . E 7 T$ & $E$ \\
\hline 10106 & -2.56 & -6.117 \\
\hline 2606 & -2.475 & $-6: 199$ \\
\hline 360 & -2.381 & - 198 \\
\hline 460 & $-2.28 \mathrm{E}$ & -1.391 \\
\hline 56196 & -2.189 & -6.489 \\
\hline E日60 & $-2 \cdot \sqrt{162}$ & $-6,515$ \\
\hline 760 & -1.899 & -8.79 \\
\hline 8日6 & -1.780 & $-19,95$ \\
\hline 960 & -1.564 & -1.113 \\
\hline 16160 & -1.31 & $-1: 36$ \\
\hline 11506 & -1.199 & -1.58 \\
\hline 1206 & -6.98 & -1 , 595 \\
\hline 13010 & -9.781 & -1.99 \\
\hline 14616 & $-1,599$ & $-2,69$ \\
\hline 15010 & -8.413 & $-2=254$ \\
\hline
\end{tabular}

\begin{tabular}{|c|c|}
\hline 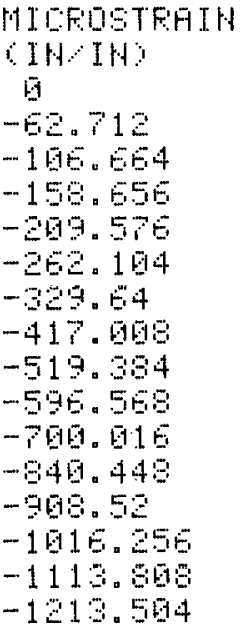 & 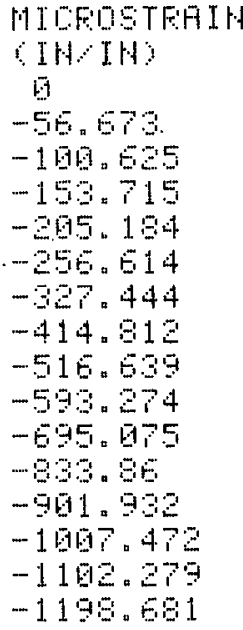 \\
\hline
\end{tabular}

\begin{tabular}{|c|c|c|c|c|}
\hline \multicolumn{5}{|c|}{$\begin{array}{l}\text { EHAHHEL = } \\
\text { ETFHIH } \\
\text { IHSTFESGEI WILTS=-2.901 }\end{array}$} \\
\hline $\begin{array}{c}\text { FFEGGUFE } \\
\text { CFGI }\end{array}$ & $\begin{array}{l}\text { STHEGGEL } \\
\text { OULTS }\end{array}$ & $\begin{array}{l}\text { IIELTH } \\
\text { WGLTS }\end{array}$ & GIHIH) & $\begin{array}{l}\text { AILFOSTFHIH } \\
\text { IHIHS }\end{array}$ \\
\hline 8 & -2.801 & $\overline{1}$ & 9 & 0 \\
\hline 1660 & $-\because . P Q E$ & -6.695 & -48.165 & $-42,12 E$ \\
\hline 2ब16 & $-2,509$ & $-6.19 \Xi$ & $-97,544$ & -91.365 \\
\hline 2006 & -2.465 & -1.95 & $-171.3 E$ & $-16 \% .425$ \\
\hline 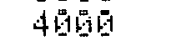 & -2.318 & $-4,4-6$ & $-244,351$ & -240.49 \\
\hline 5606 & -2.17 & -5.631 & -919.917 & -314.427 \\
\hline E616日 & -2.51 & $-8 \cdot 7 \vec{i}$ & -390.39 & $-396,194$ \\
\hline 7日10日 & -1.892 & -10.919 & -40.93 & $489 ? 9$ \\
\hline 8606 & -1.735 & $-1.9 E$ & -540.482 & $-537 \cdot 717$ \\
\hline 9606 & -1.634 & -1.187 & -591.659 & -595 ․ \\
\hline 1601 & -1.495 & -1.36 & $-E E Z 14 Z$ & $-657 \cdot 261$ \\
\hline 115.96 & $-1.31:$ & -1.485 & -754.415 & -747.928 \\
\hline 12060 & -1.229 & -1.572 & -797.014 & $-796.41 E$ \\
\hline $1: 6019$ & -1.197 & $-1,54$ & $-956,65$ & -950.974 \\
\hline 1450.9 & -5.99 & $-1,811$ & -919.177 & -960.69 \\
\hline 15016 & -6.980 & -1.913 & -969.691 & $-955,569$ \\
\hline
\end{tabular}


DHAHHEL $=1 \mathrm{~B}$

STFHINHOLT = 517

DHSTFESEEI UOLTS=-2.919

FRE GUPE STRESST

ESI

Q UOLTES

1060

2600

3060

40151

50106

B日6日

70109

8969

9606

1606

11560

12000

13000

14060

15060
$-2.918$

$-2.759$

$-2.684$

$-2.975$

$-2,15$

aㅔ 1.97

$-1,671$

$-1.429$

$-1=185$

$-1,612$

$-9.77$

$-9.469$

$-4.32$

$-0.098$

6.195

0.365
DELTTF

WOLTE

G

$-6.159$

$-8.214$

$-6.543$

-

- 1 : $1: 2$

$-1.247$

$-1,499$

$-1.73$

$-1.996$

$-2.144$

$-2,449$

$-255$

$-2.8 \mathrm{e}$

$-3.923$

$-3.223$
WIOFOETEAIH
G IH

$-82,29$

$-162.39$

- 280.731

$-4077$

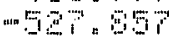

$-544.699$

$-769.813$

$-895.961$

$-995,462$

$-1108.448$

$-126,193$

$-1341,615$

$-1457 \cdot 94$

$-1562.991$

$-1660.291$
MICEOSTFAIH

IH IH)

6

$-7 E, 164$

$-156,299$

$-275.79$

$-399.395$

- 52,30

$-642.56$

-767 \% 617

$-993.216$

$-982,165$

$-1103.567$

$-1259.545$

$-1395.627$

$-149.150$

$-1551.962$

$-165.168$

CHAHHAL = IE

STFFIF MOLT $=513$

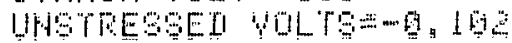

\section{FFESEIJFE}

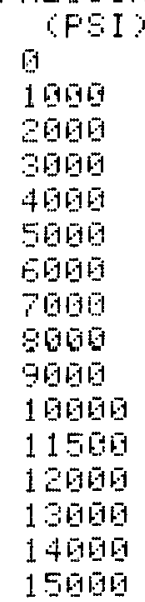

TTESET

UDLTS

$-8 \cdot 192$

4. 579

1. 689

9.892

1.692

1.219

1. 392

1. 58

1. 746

1.871

2.94

206

2.36

2.595

2. 674

2,32
DEL THF

WILTS

目

更 $4+101$

$-0.71$

$-8.934$

$-1,34$

$-1.321$

$-1.494$

따. 1.71

$-1.94$

$-1.973$

$-2.142$

in.

$-2.471$

$-2.697$

2.76

2.925
MIROSTFAI

II I I H

6

240,75

$-304.23$

$-479.142$

$-501,742$

- $-67 \% .673$

$-756.422$

- 95,292

$-945.64$

$-1012.149$

$-1698.845$

1.210.750

$-1267,623$

$-1352.791$

$-1424.658$

$-1499.499$
MIEFOETFAI

(IHI)

G

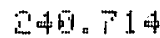

$-356 \cdot 191$

$-474,291$

$-577.35$

- E72.195

$-764,225$

$-855.627$

$-945.270$

$-1068.85$

$-1693.965$

1297.17

$-1261,65$

$-1348.997$

$-1412.55$

$-1494.676$ 
CHAHAHEL $=2$

STRAIH WOLT = 520

UNATRESSEI YILTS=-2.EBE

FRESEURE

(FSI?

1000

2006

3000

401018

5060

E060

7 저엉

8060

9060

16960

11566

12606

13600

140619

15606
STREESEI

CULTS

$-2.609$

$-2.591$

$-2.450$

$-2.495$

$-2.466$

$-2.39$

$-2.294$

$-2.166$

$-2.927$

$-1.923$

$-1.786$

$-1.665$

$-1.515$

$-1.38$

$-1.256$

$-1.128$
TELTHA

VOLTS

G

$-6.107$

$-9.15$

$-6.123$

- -1.1 at

$-6.21$

$-9.314$

$-6.442$

$-6,591$

$-6.685$

$-9.62$

$-1.019$

$-1.099$

$-1.23$

$-1,352$

$-1.49$
MICFOETPATH

(IHA IH)

8

$-5.5 .64$

$-7 \mathrm{~s}$

$-63.96$

$-73.94$

$-169.2$

$-163.28$

$-229.84$

$-302.12$

$-356,2$

$-427.44$

$-521.50$

$-569,36$

$-639$

$-703.94$

$-769.6$
MIEROTEATH

CIH IH?

更

$-49.611$

$-71.951$

$-59,019$

$-69.448$

$-163.71$

$-161.084$

$-227.644$

$-299.375$

$-352.906$

$-422.499$

$-514.972$

$-5 E 1.772$

$-630.816$

$-691.511$

$-754.777$

CHFHAHEL $=20$

STRAIN VULT $=524$

DHSTFESSEI YULTS=-2.224

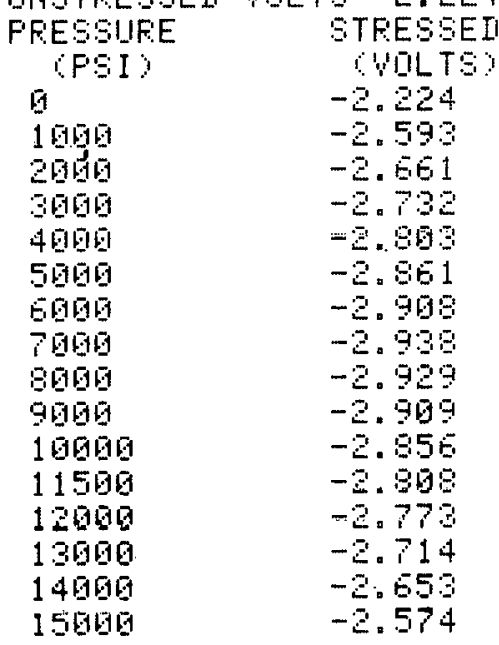

DELTH

VOLTS

G

G.

Q. 437

9. 5.98

日.

G. 637

9.684

9. 714

6. 785

Q.685

0.62

0.584

0.549

6.49

9. 429

1. 35
MIOROTFATH

CIN IH?

回

193,356

220,98

260.192

3ty.y

33.78

358.416

374.136

369.42

358.94

331.16

306. 15

297,676

25E.78

224.795

193.4
HICEOSTEAIH II I I I

日

199.395

$25 \%, 627$

271.133

397.78

290.278

30.6.

376.32

372.165

32.234

396.109

12. 604

29. 264

265.544

235.325

198.223 


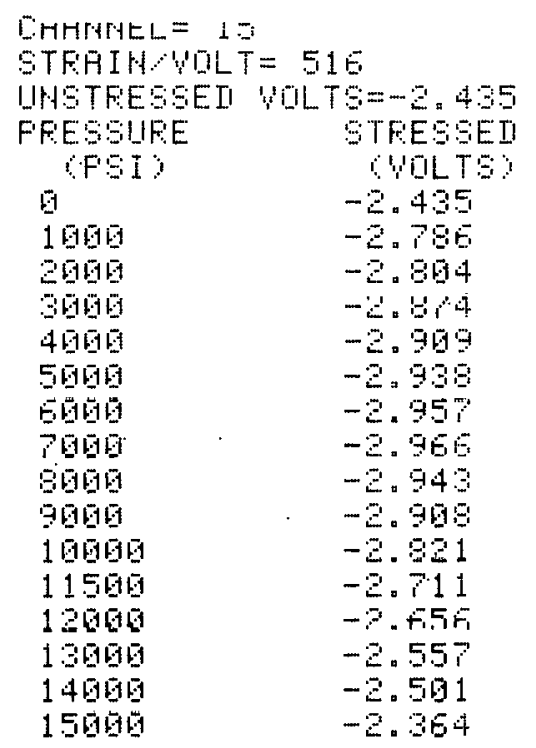

CHAHAHEL $=19$

STFEINWLT = 542

UPSTRESSEI WITTE=-2,749

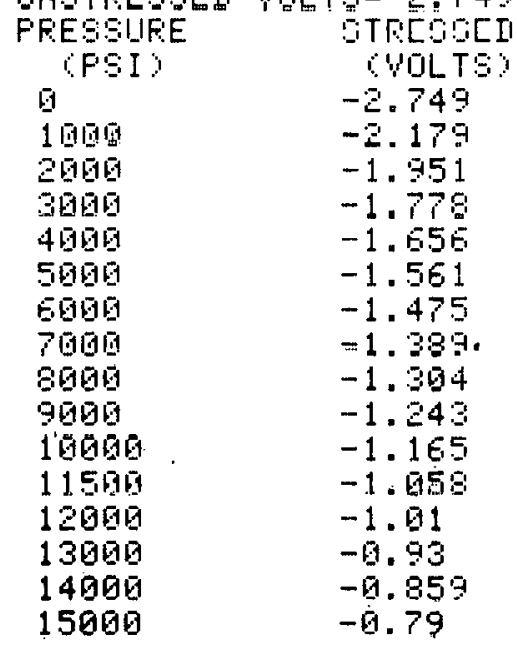

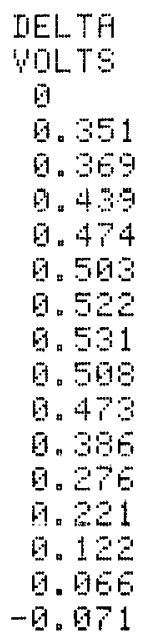

\author{
MIEFESTEAIH \\ CIt It? \\ MIDFIOTFAIH \\ I It It
}

9

$181.11 \mathrm{E}$

190.464

226,524

244.564

259.545

269.35

273.995

262,126

244.968

199.175

$142,41 E$

114,50

82.952

34. 056

$-36.58$
业

197.155

195.449

231.45

245.975

265. 135

271.548

275. 192

264. 573

24.362

244.117

149. 194

126,54

71.735

45,595

$-21.913$
IIELTHE

WOLTS

G

$-9.57$

- 1.798

$-0.971$

$-1.093$

$-1.188$

$-1.274$

$-1.35$

$-1.445$

$-1.506$

$-1.584$

$-1.61$

$-1.739$

$-1.819$

$-1.89$

$-1.959$

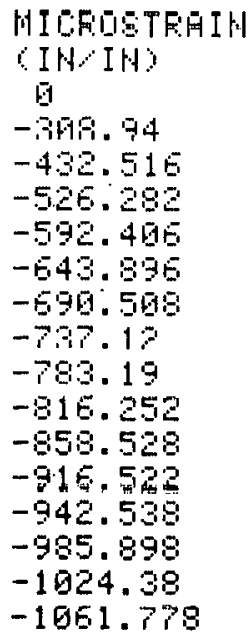

HIERTETEH 1 H (IH IH) G

$-362,901$

$-426.477$

$-521.341$

$-585.014$

$-638.406$

$-688.312$

$-734: 924$

$-789.445$

$-812.958$

$-653.587$

$-969.934$

$-935.95$

$-977.114$

$-1012.851$

$-1046.955$ 


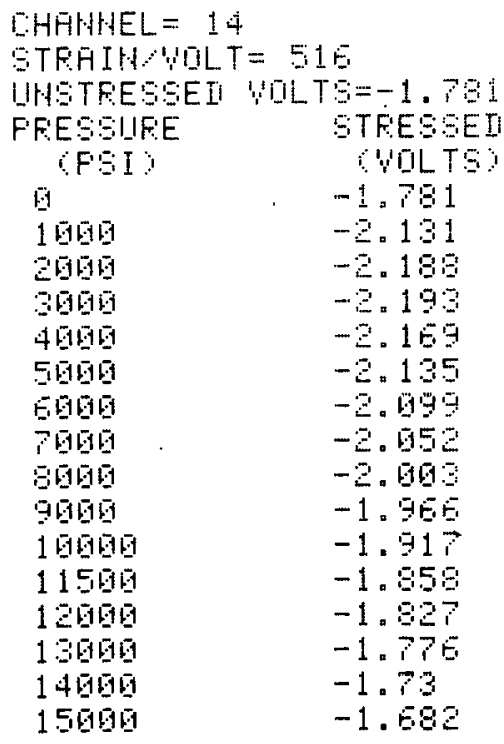

E.HAPNAEL $=13$

STFAINWLT = 512 IHSTRESSEI WDLTS=-2.584

\begin{tabular}{|c|c|}
\hline 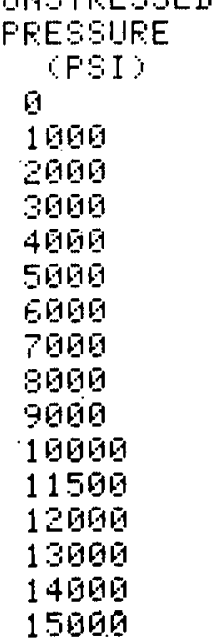 & $\begin{array}{c}\text { STEESGEI } \\
6 \text { WLTS } \\
-2.584 \\
-3.959 \\
-3.149 \\
-3.179 \\
-3.132 \\
-3.176 \\
-3.161 \\
-3.139 \\
-3.117 \\
-3.191 \\
-3.975 \\
-3.053 \\
-3.94 \\
-3.013 \\
-2.991 \\
-2.965\end{array}$ \\
\hline
\end{tabular}

\begin{tabular}{|c|c|}
\hline DEL.TH & MIEFOGTFAIH \\
\hline GITSE & It I I H \\
\hline$\overline{0}$ & 0 \\
\hline 0.95 & 150.6 \\
\hline 4.407 & 210.612 \\
\hline 0.412 & 212.592 \\
\hline 0.96 & 2010208 \\
\hline 1.:- : & 182.654 \\
\hline 0.918 & $1 E 4.58$ \\
\hline 0.27 & 139685 \\
\hline 0.23 & 114.5 .52 \\
\hline 0.185 & $95 \cdot 4 E$ \\
\hline $9.13 E$ & $76.17 \mathrm{E}$ \\
\hline 5.977 & 39.722 \\
\hline 0.546 & $23 \times 735$ \\
\hline$-5.00019 E-03$ & -2.58 \\
\hline $\begin{array}{l}-0.0151 \\
-0.695\end{array}$ & $\begin{array}{l}-25,316 \\
-51,654\end{array}$ \\
\hline
\end{tabular}

WIIEOBTFAIH (It) I th) G 15699 215,051 217.59 264.6 189.154 165.294 142.62 117.297 98.754 75.117 4E. 3 36.24 E. 204 $-14.787$ - JE. 251

IELTH
ULTS
0
0.475
0.559
0.594
0.598
0.592
0.577
0.5 .54
0.593
0.517
0.494
0.469
0.456
0.429
0.407
0.381

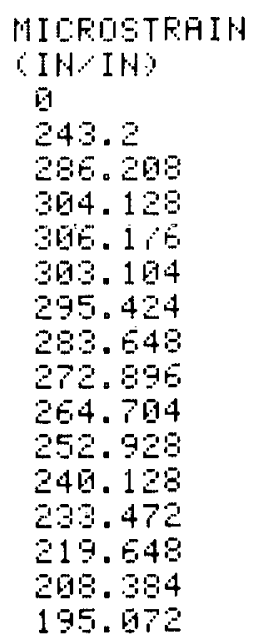

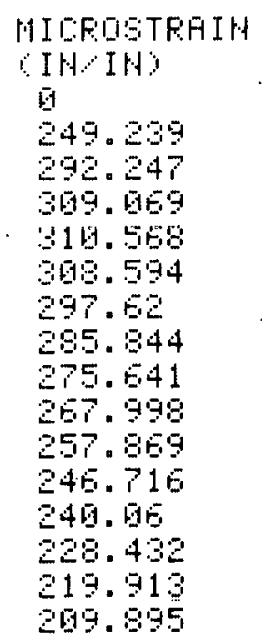




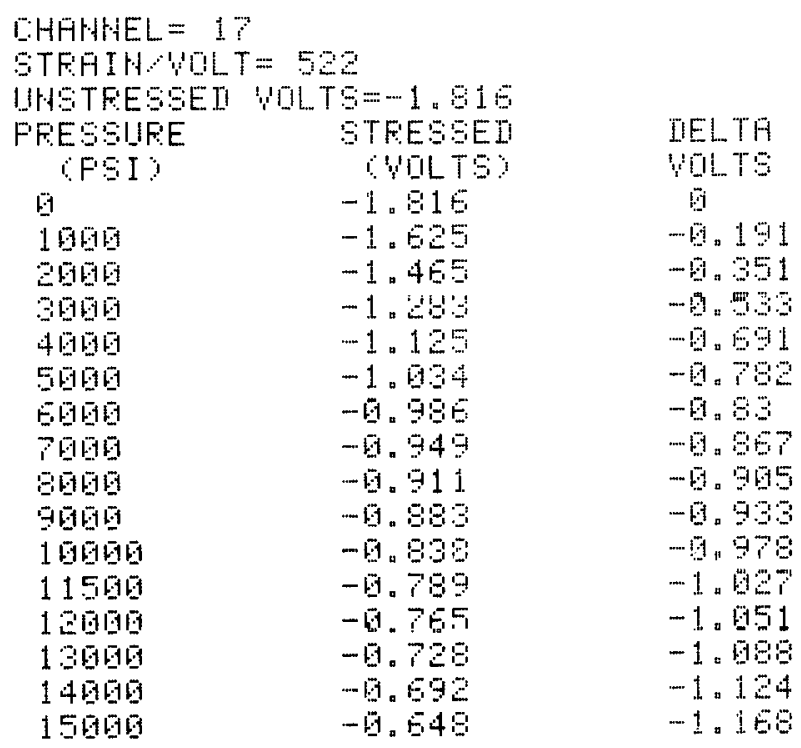

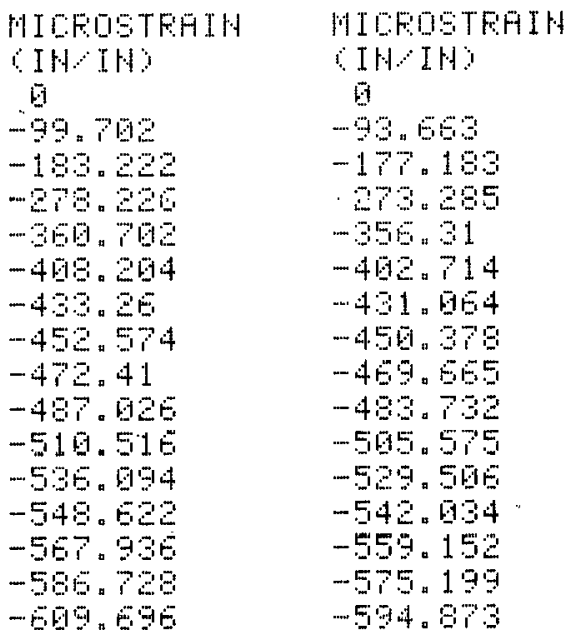

E.HAH.HAL $=21$

STFAIHALT = $5 \mathrm{BS}$

UWSTFESEET YOLTS=-2, 191

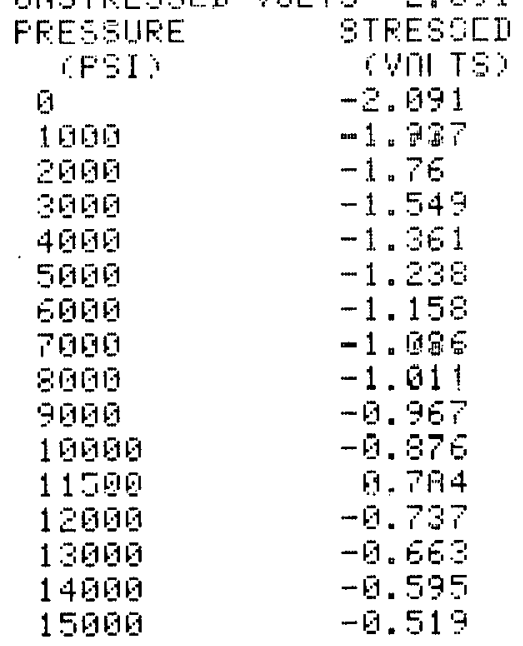

DELTHA

ULLTS

G

$-3.154$

$-5,31$

$-0,542$

$-6,73$

$-9.95$

$-0.939$

$-1.919$

$-1.68$

$-1.124$

$-1.215$

$-1.957$

$-1.954$

$-1.429$

$-1.495$

$-1,572$

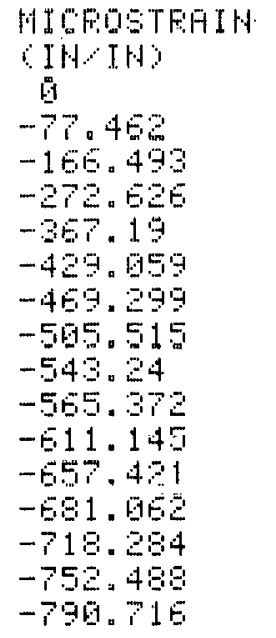

PITFTETFEIH

It? IH

b

$-71.423$

$-160.454$

- 267 . 685

- 302 . 798

$-423.569$

$-4 E 7.163$

$-502,319$

$-546.49$

$-5.678$

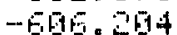

- $550.93 \%$

$-674.47$

-799. 5

$-740.959$

$-775.903$ 


\begin{tabular}{|c|c|c|}
\hline $\begin{array}{l}\text { БHAHAHEL } \\
\text { GTFA IHA } \\
\text { DHSTFESGE }\end{array}$ & $1.5=-2.51$ & \\
\hline $\begin{array}{c}\text { FFESGIFE } \\
\text { FGI }\end{array}$ & $\begin{array}{r}\text { GTFEGSEI } \\
\text { GULTS }\end{array}$ & $\begin{array}{l}\text { IELTH } \\
\text { WLTS }\end{array}$ \\
\hline 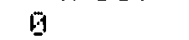 & - E. E & 国 \\
\hline 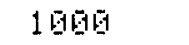 & -2.51 & -6.15 \\
\hline 2060 & -2.375 & -6.305 \\
\hline 30106 & $-2.2 Z$ & -6.459 \\
\hline 4610日 & -2.997 & -5.564 \\
\hline 56日10 & -1.979 & $-6,75$ \\
\hline 6日10日 & -1.895 & $-6,79$ \\
\hline 7806 & -1.81 & -8.96 \\
\hline 8000 & -1.712 & - 1.96 \\
\hline 96010 & -1.543 & -1.610 \\
\hline 15015 & -1.569 & -1.112 \\
\hline $115 \overline{15}$ & -1.472 & -1.209 \\
\hline 12006 & -1.423 & -1.25 \\
\hline 13600 & $-1 .: 47$ & -1.34 \\
\hline 14610 & -1.28 & -1.099 \\
\hline 15.56 & $-1.21 ?$ & -1.404 \\
\hline
\end{tabular}

\begin{tabular}{|c|}
\hline 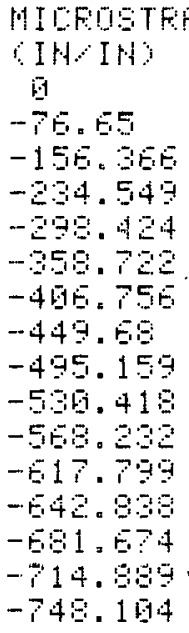 \\
\hline
\end{tabular}

MIOROSTFFIH

It IH?

5

$-7, E 11$

-150 , 32

$-223.610$

$-294.93$

$-35.23$

$-46 \% 56$

$-44.454$

$-492414$

$-57+194$

$-50.91$

- 11.211

-

$-672=9$

- 7 6

-71 201 


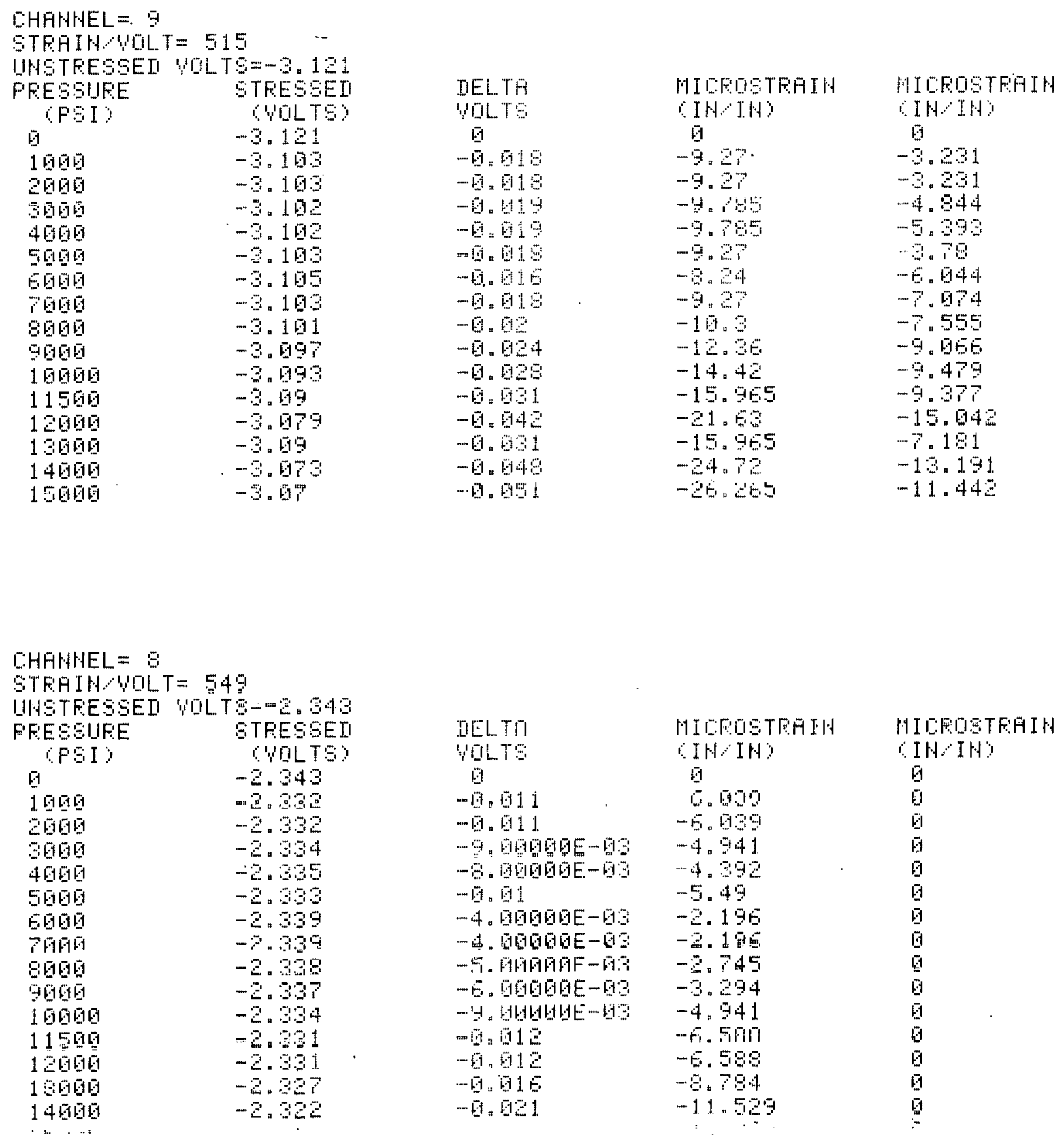




\section{APPENDIX E}

PROGRAM TO PLOT COMPARISON DATA (Graphical Output is Provided in Appendix F)

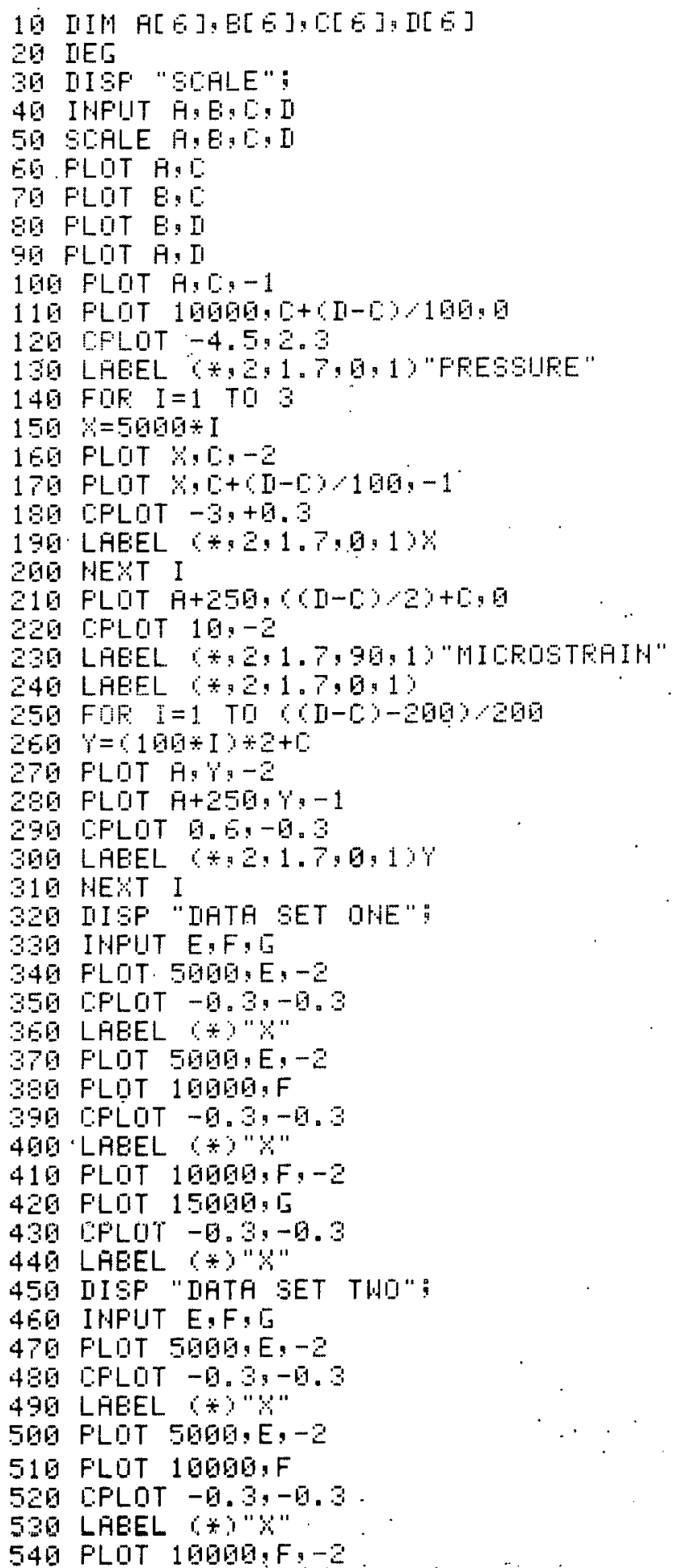

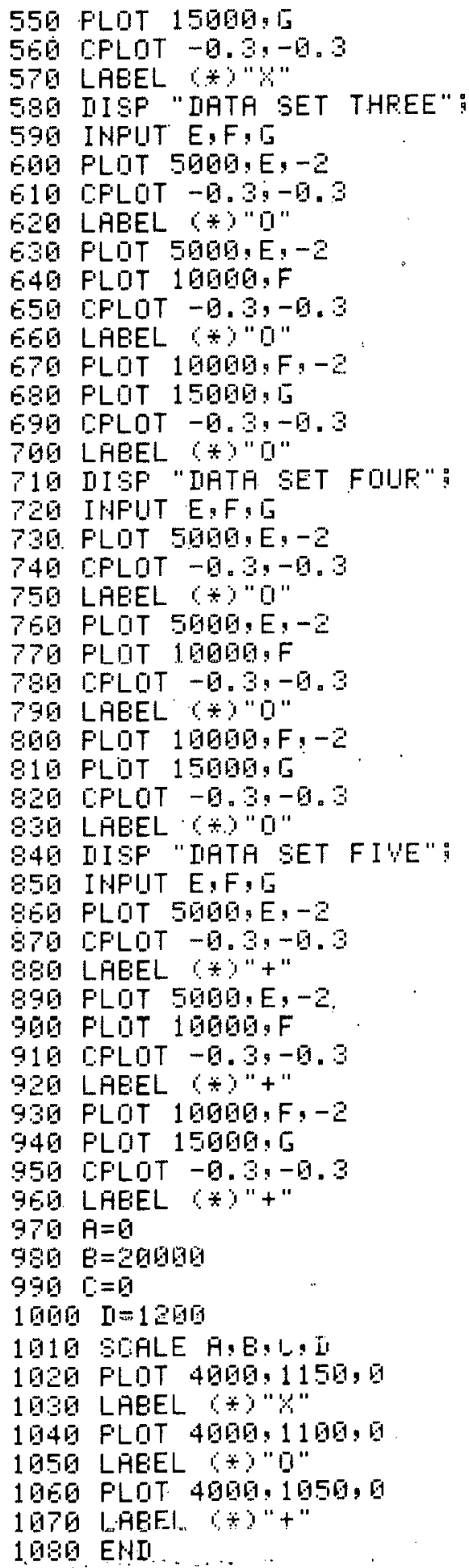


APPENDIX F

GRAPHIC COMPARISONS

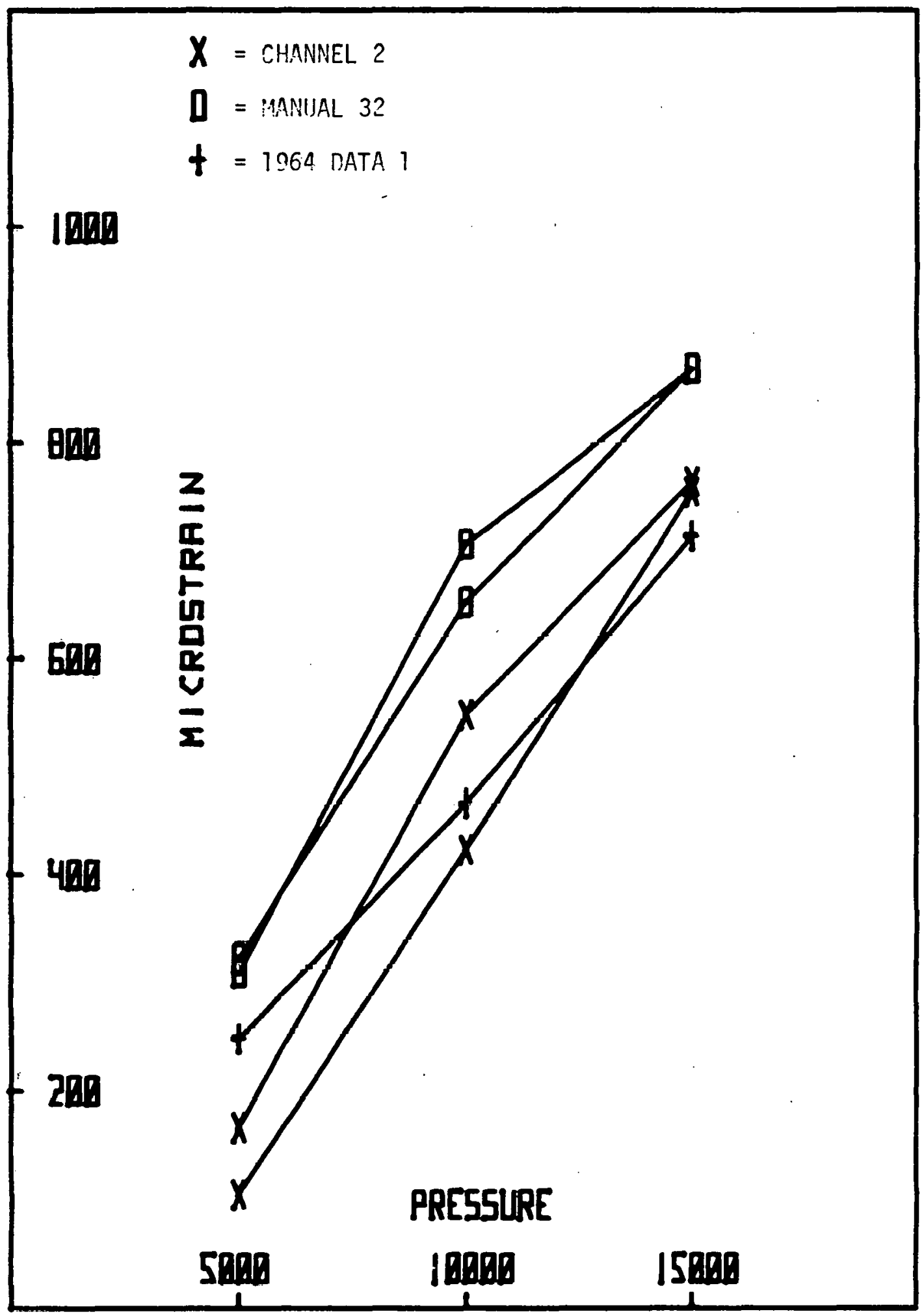




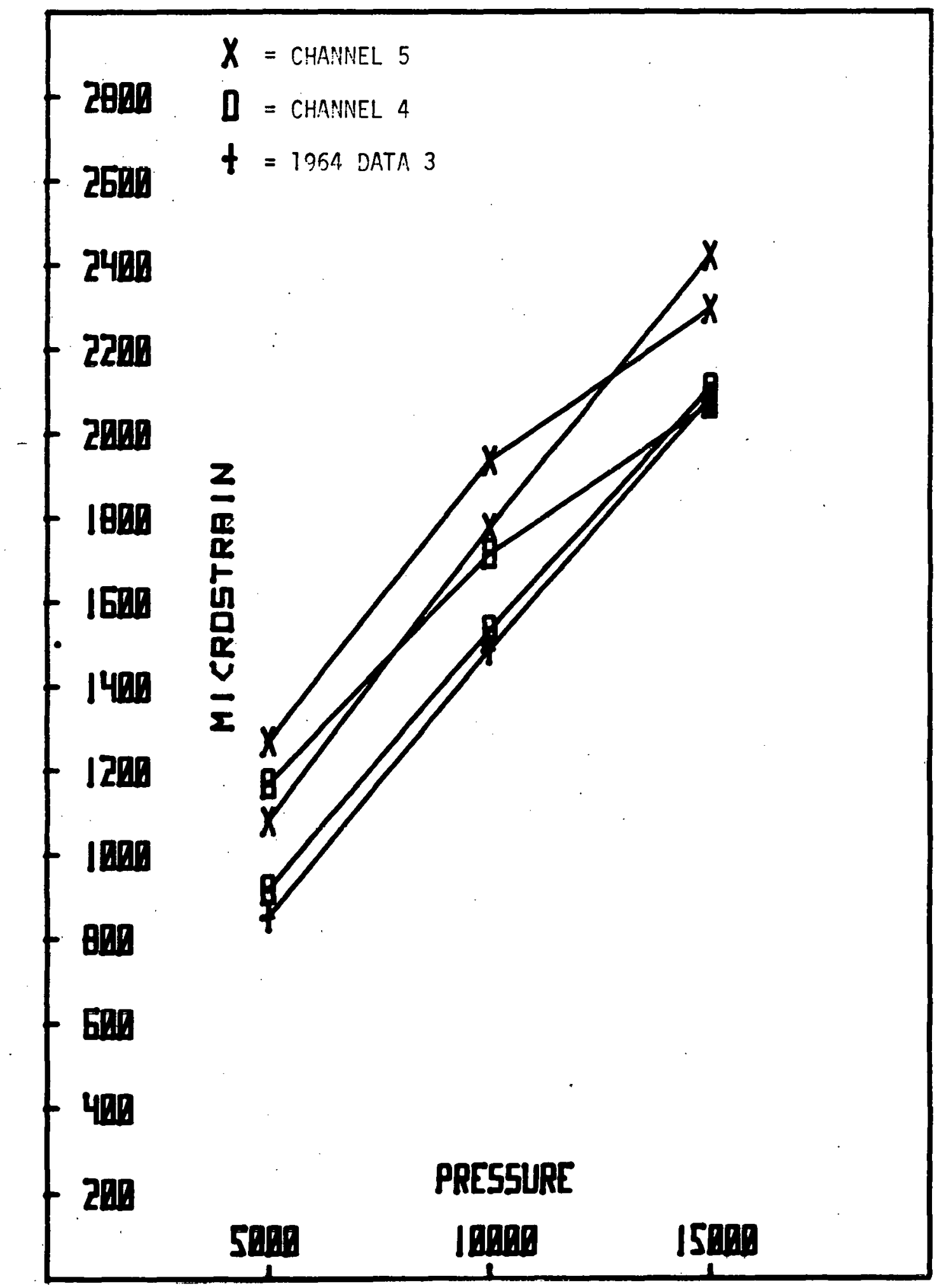




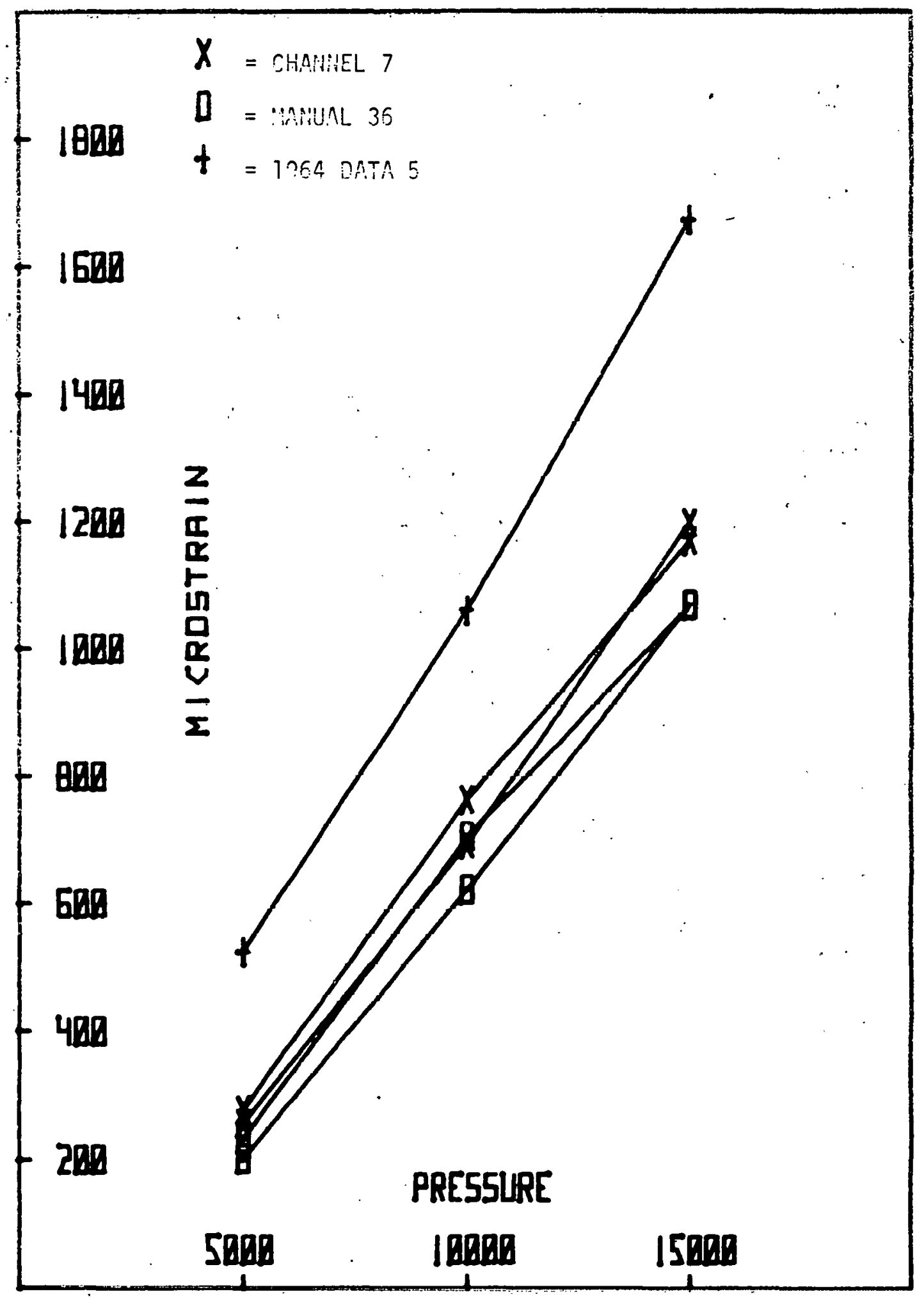




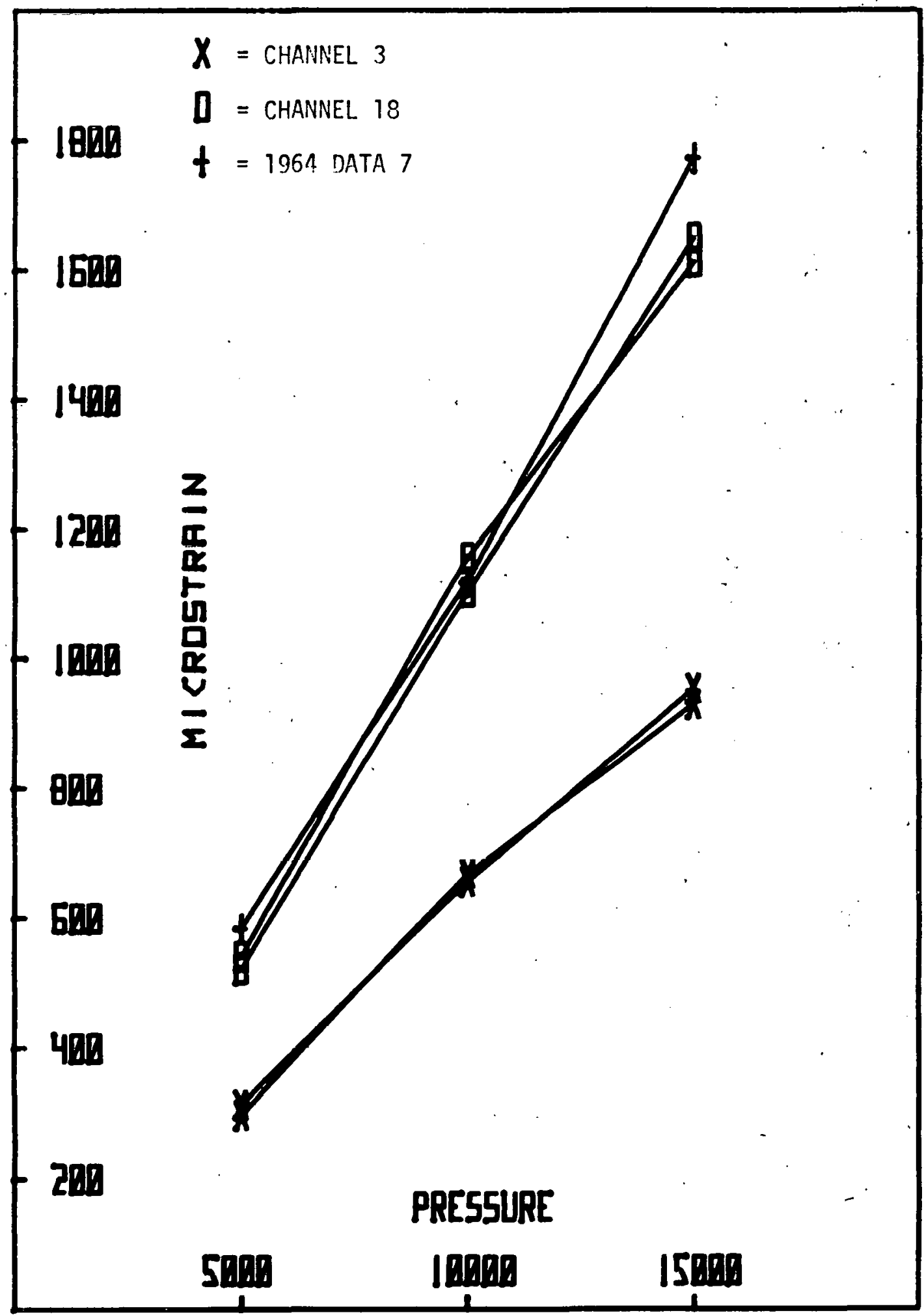




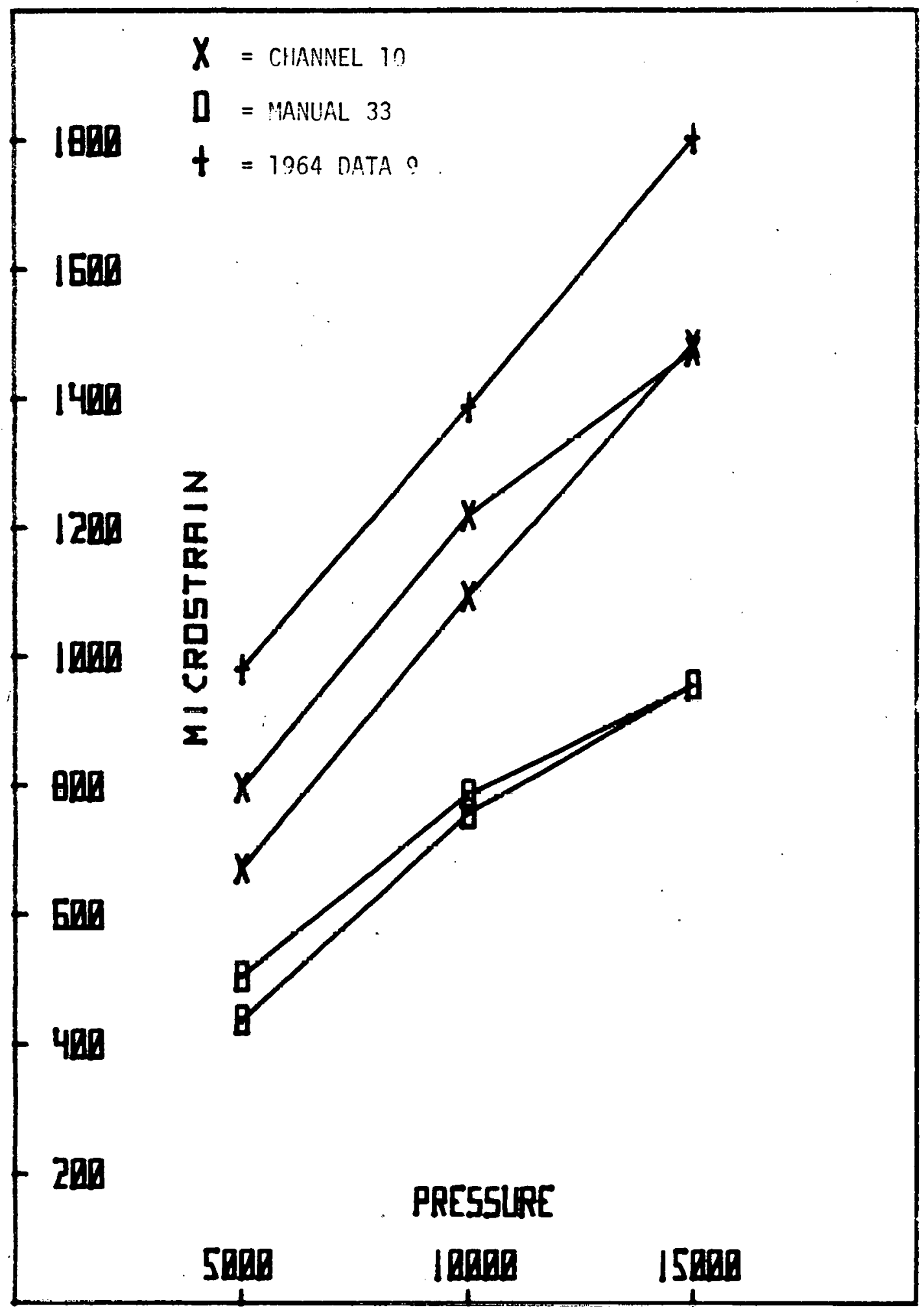




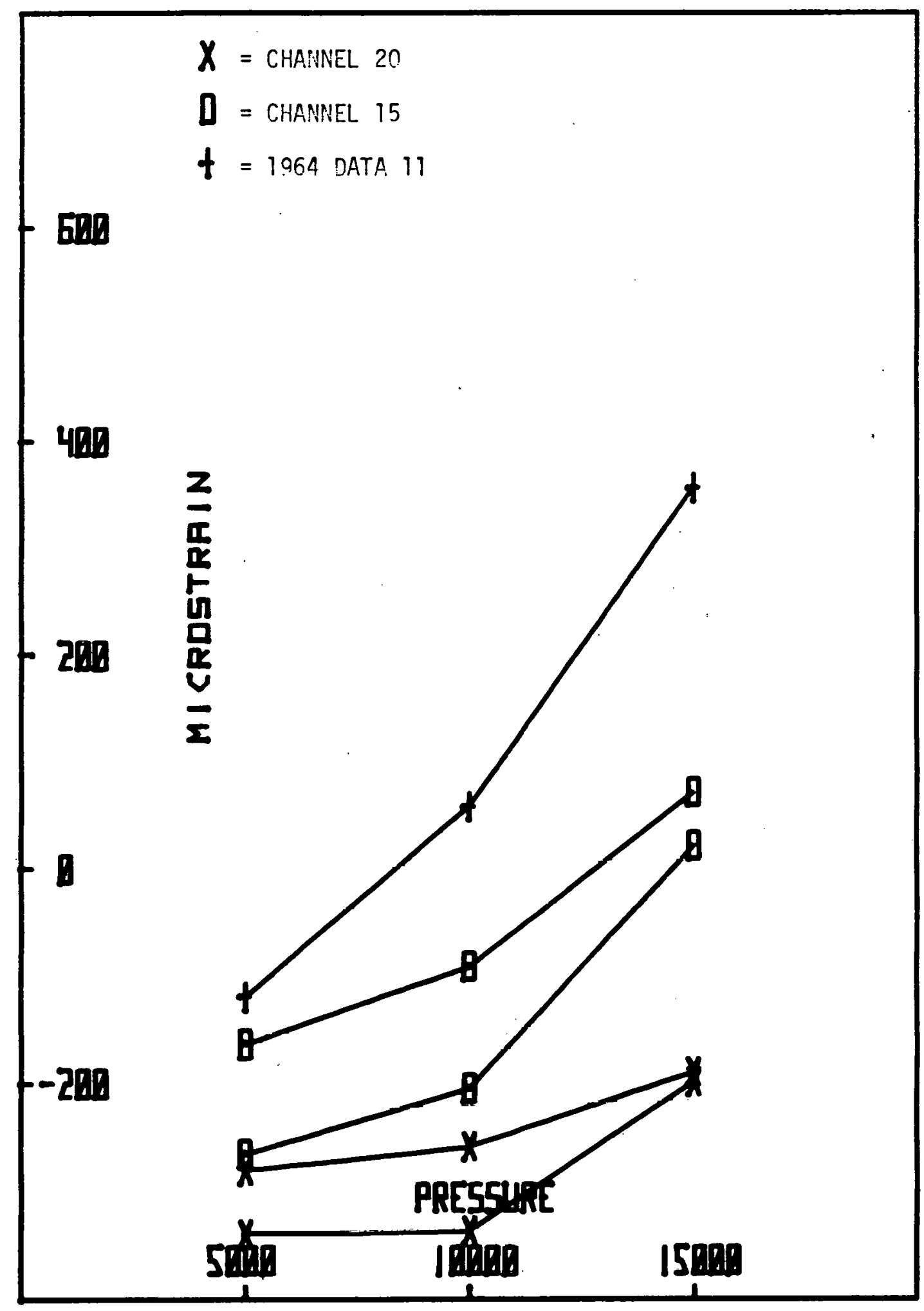




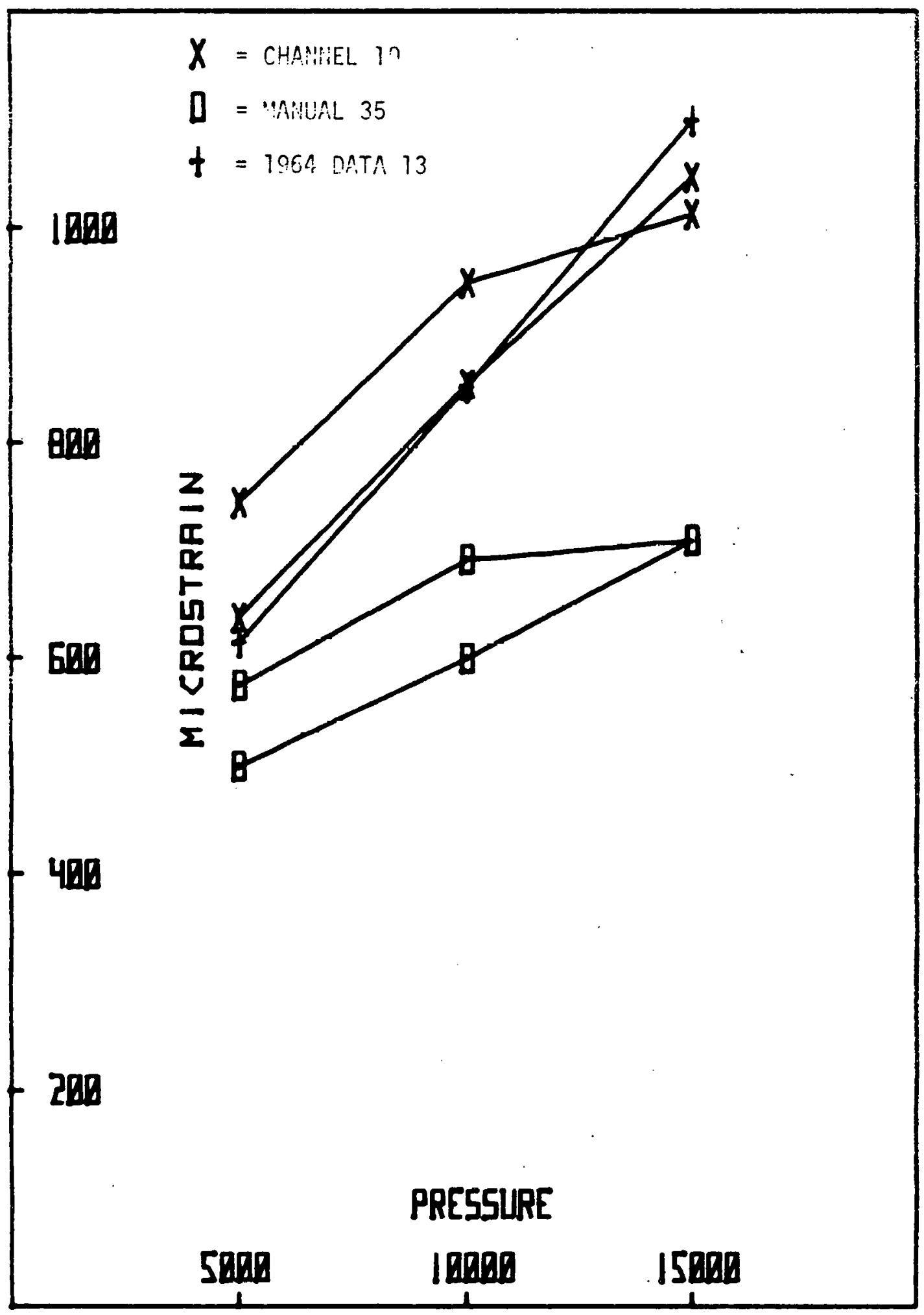




$$
\begin{aligned}
& \boldsymbol{X}=\text { CHNMELL } 14 \\
& \mathbf{D}=\text { CHNMNEL } 13 \\
& \boldsymbol{t}=1 \text { ?.G4 DATA } 15
\end{aligned}
$$

$-520$

400

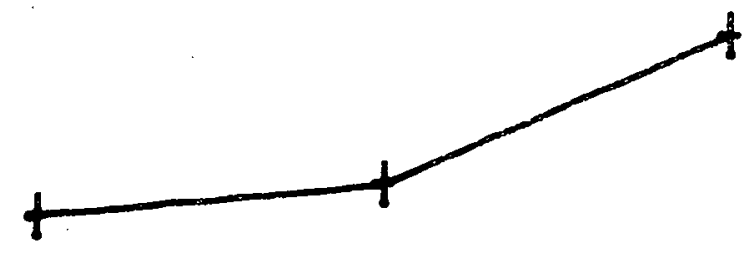

$\left[\begin{array}{l}0 \\ -200\end{array}\right.$

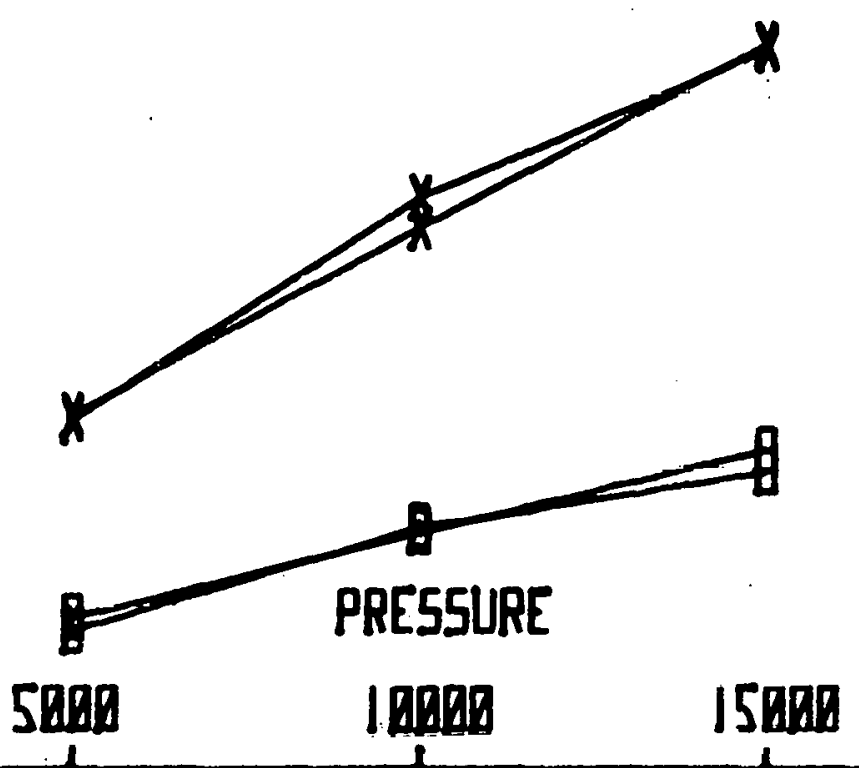




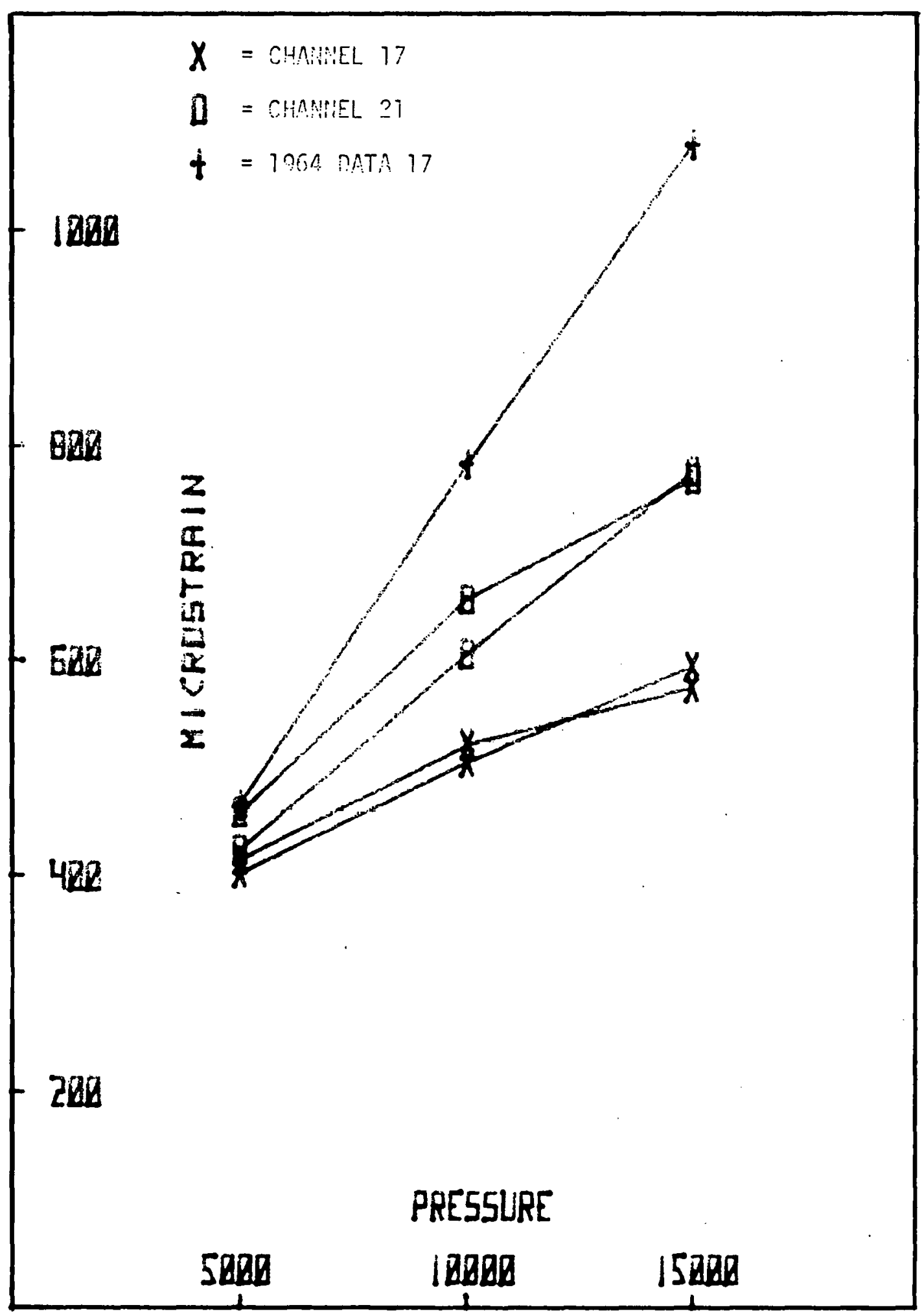




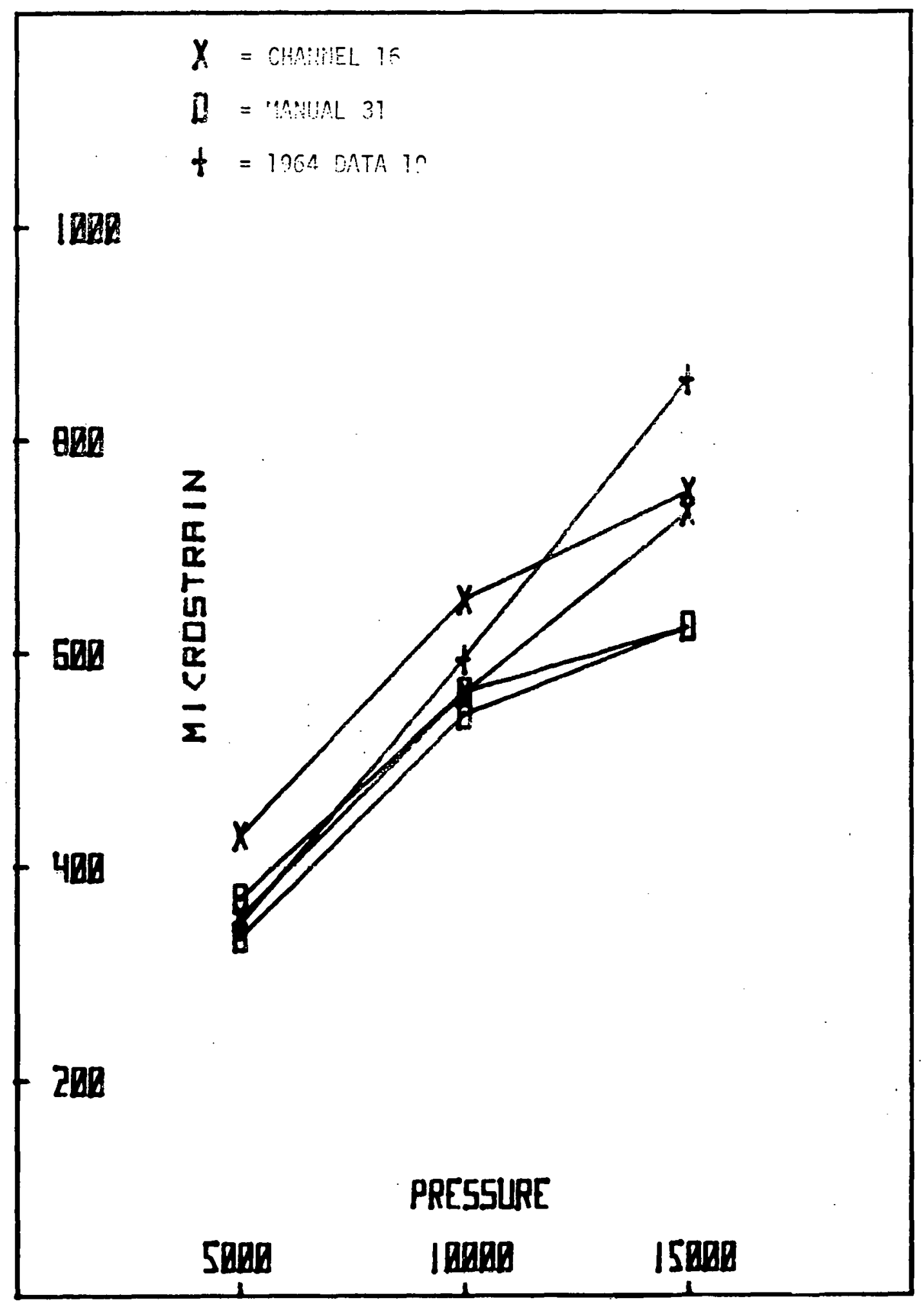




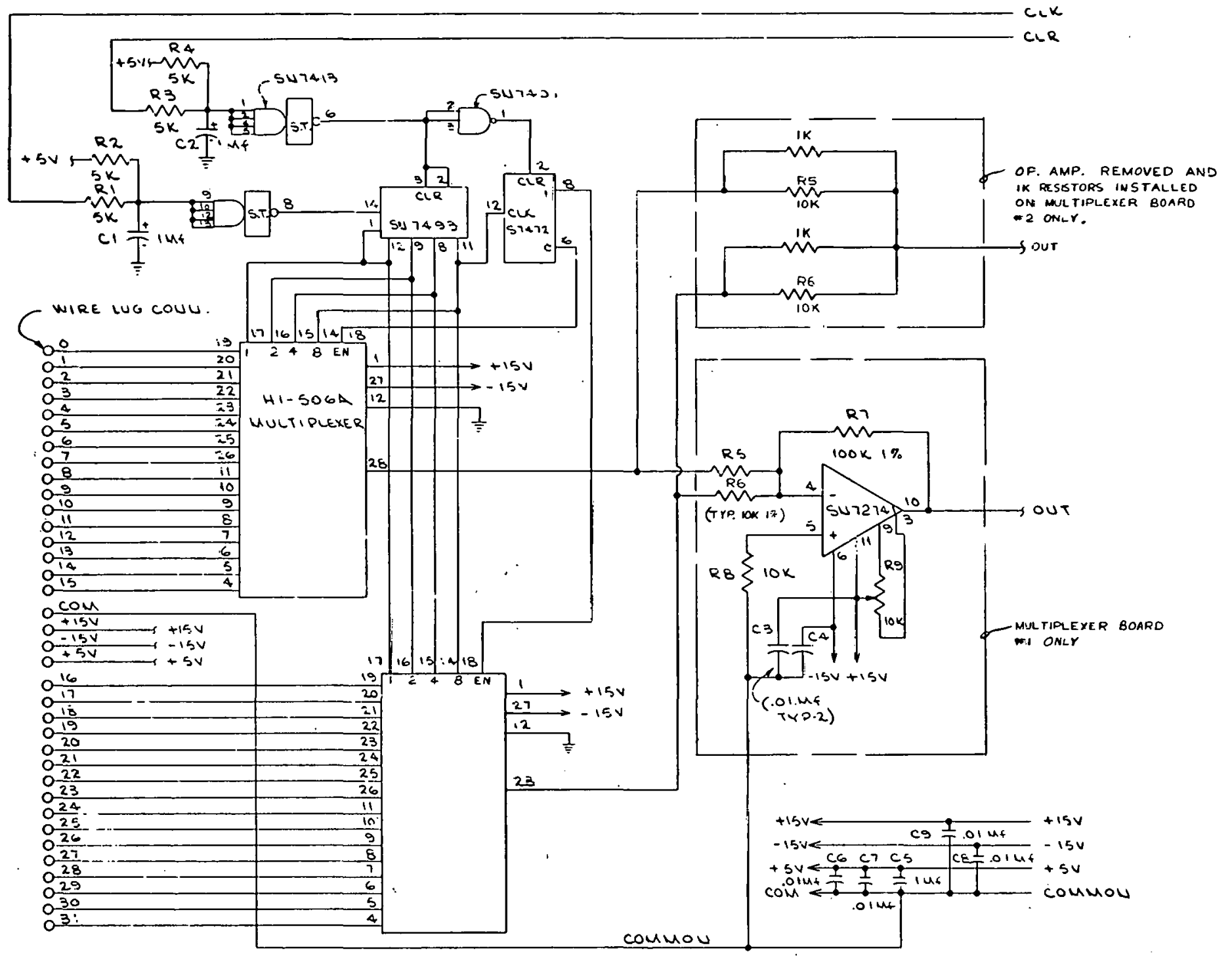

Figure Gi-1. MULTIPLEXER SCHEMATIC. 


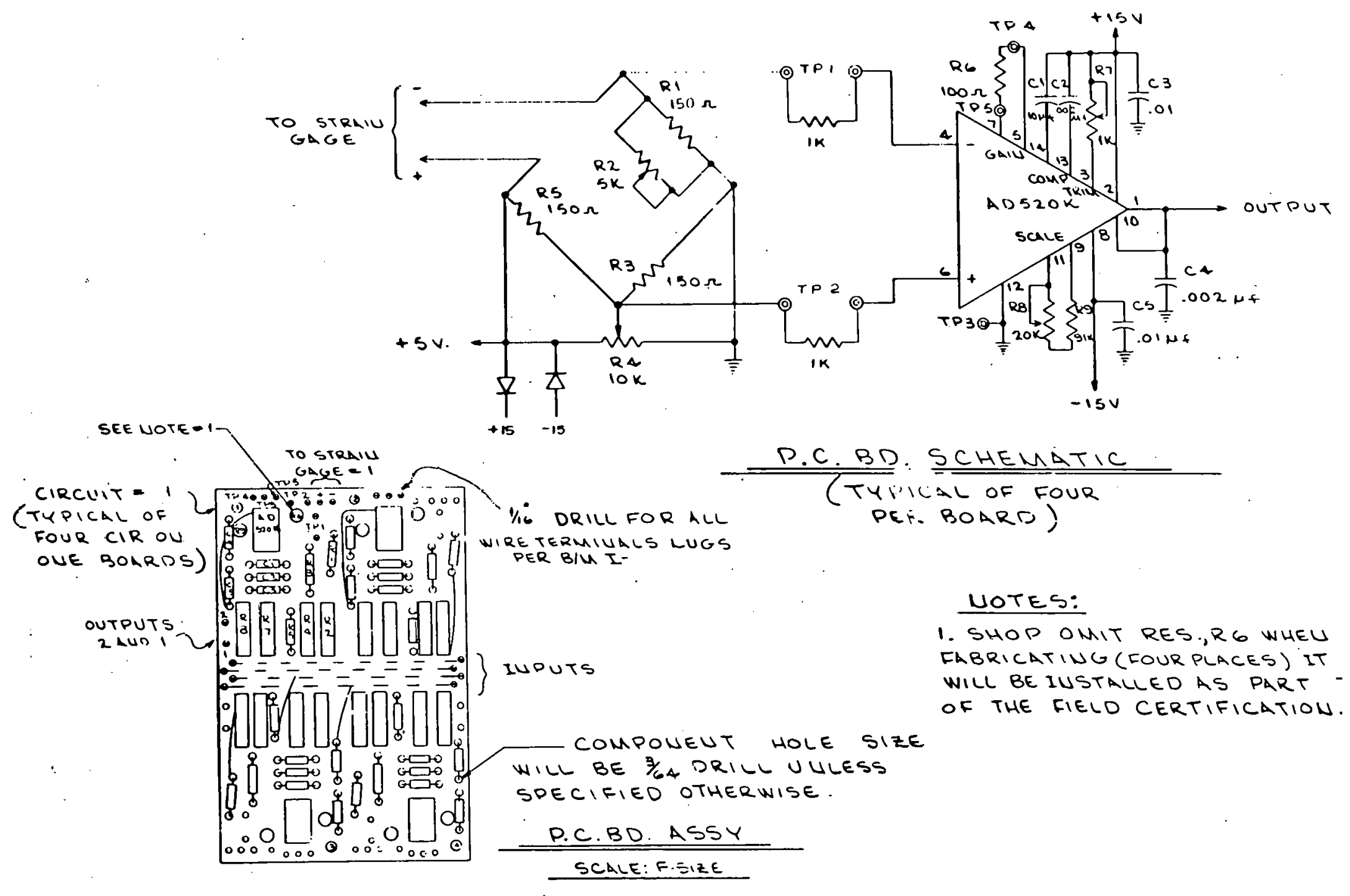

Figure G.2. STRAIN GAGE SCHEMATIC. 


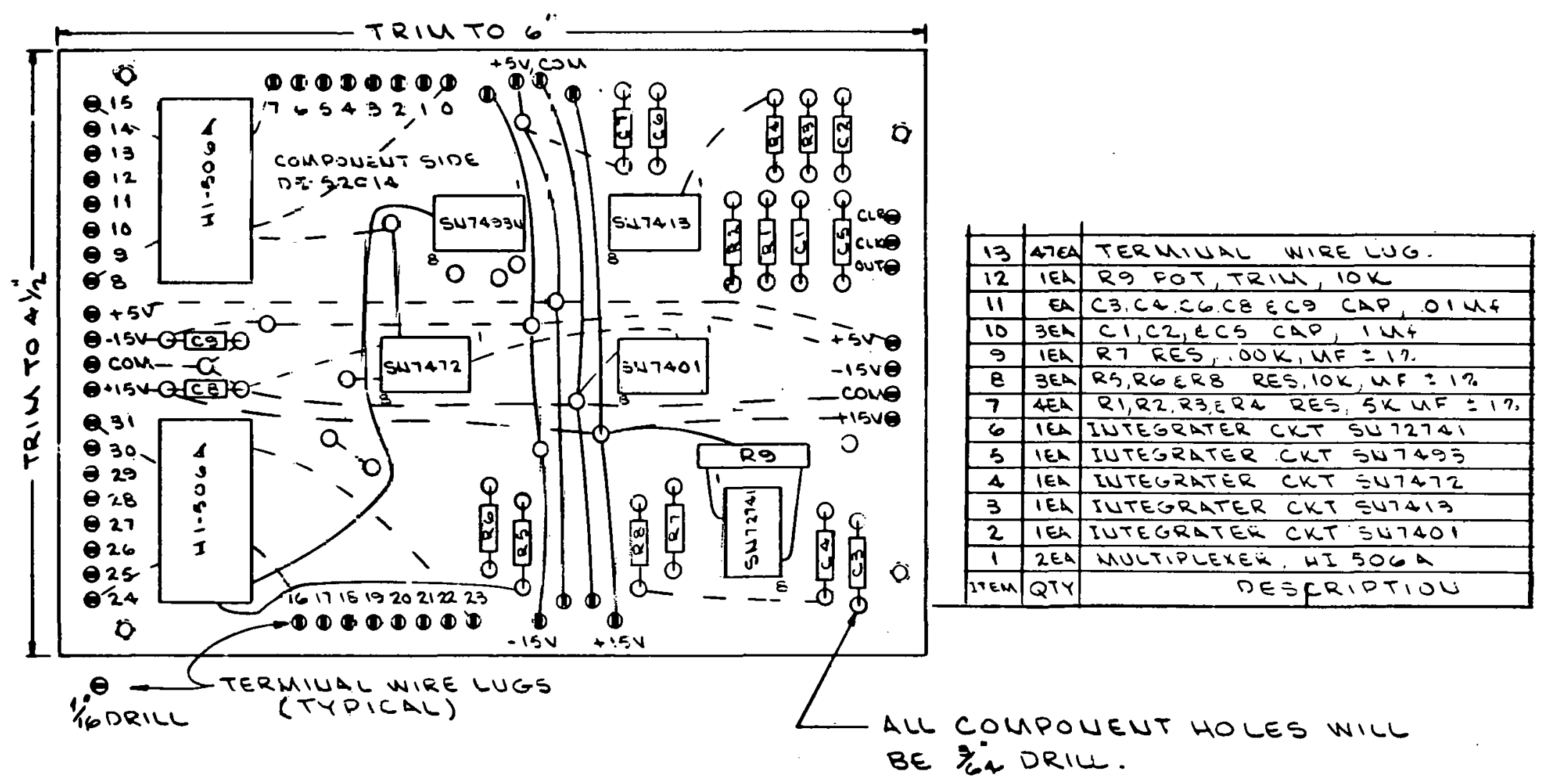

Figure G-3. PRINTED CIRCUIT BOARD ASSEMBLY. 


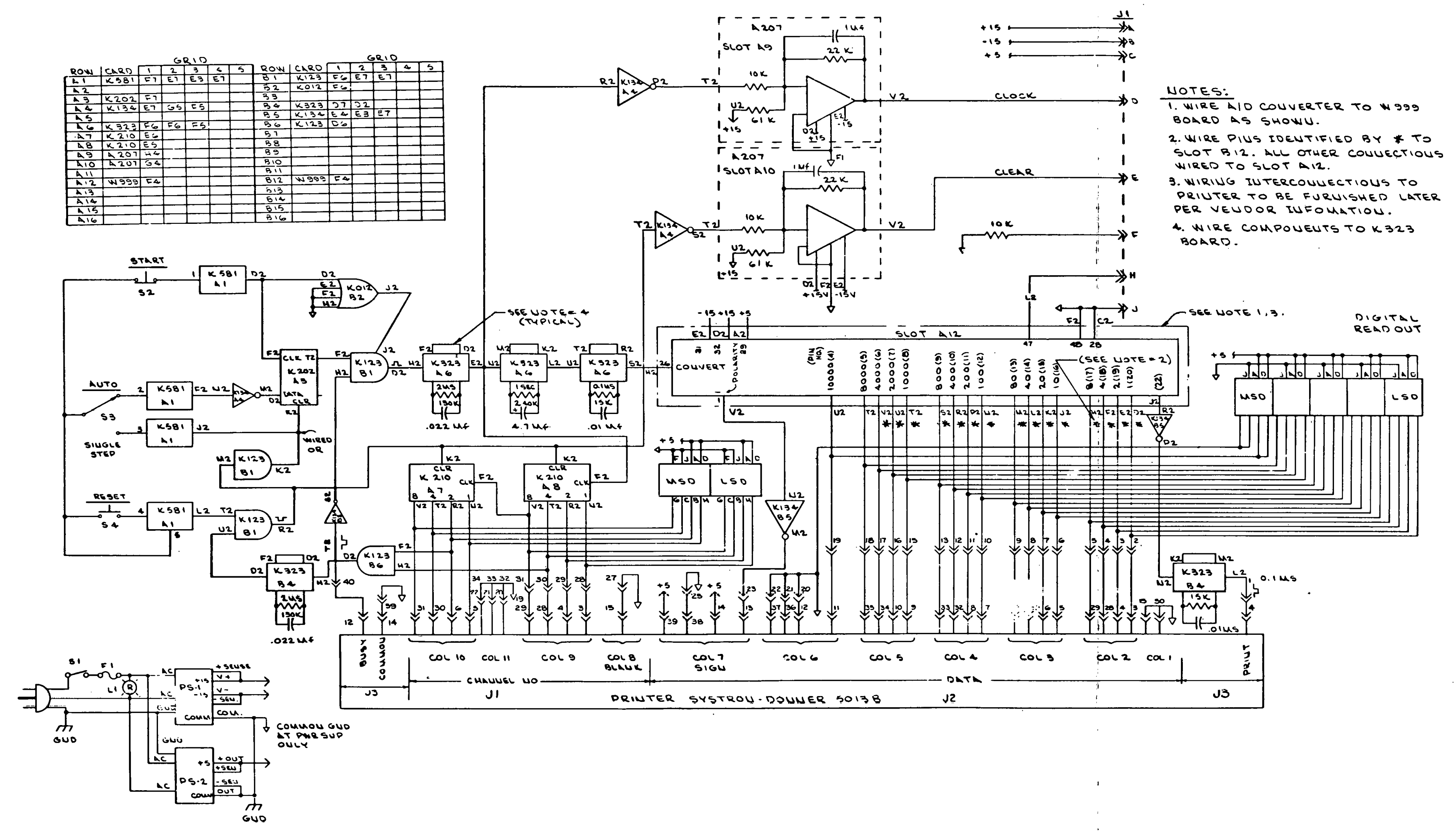

Figure G.4. CONTROL CABINET SCHEMATIC. 


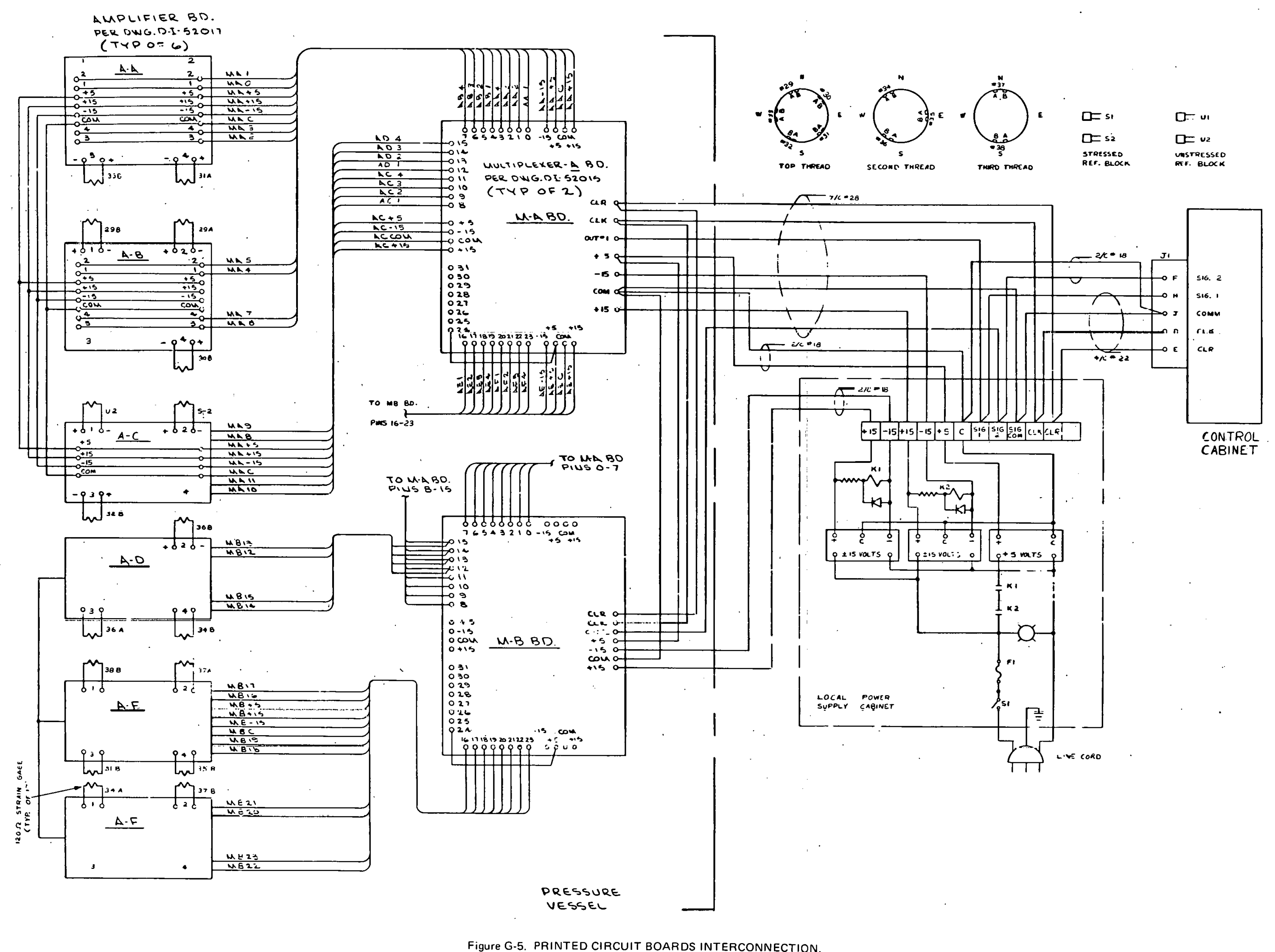




\section{Distribution}

Energy Research and Development

Smith, R. D.

Administration - Oak Ridge

Stanton, J. A.

Hickman, H. D.

Leed, R. E.

Zachry, D. S., Jr

Stoner, H. H.

Tewes, W. E.

Valentine, C. K. (2)

Weathersby, W. E.

White, J. C.

Oak Ridge Gaseous Diffusion Plant

Whitson, W. K.

Stief, S. S.

Wilcox, W. J., Jr

\section{Oak Ridge Y-12 Plant}

Alvey, H. E.

Bernander, N. K.

Briscoe, O. W.

Burditt, R. B.

Burkhart, L. E.

Duggan, $H$. G.

Ellingson, R. D.

Williams, R. D.

Yaggi, W. J./Googin, J. M.

$Y-12$ Central Files (5)

$Y-12$ Central Files (master copy)

$Y-12$ Central Files (route copy)

$Y-12$ Central Files ( $Y$-12RC)

Zerby, C. D.

Paducah Gaseous Diffusion Plant

Foulk, D. L.

Fraser, R. J.

Greene, H. T., Jr

Gritzner, V. B.

Jackson, V. C.

Jones, F. W.

Jones, R. M.

Kahl, K. G.

Keith, A.

Kite, H. T. (20)

Kowalewski, J. A.

Long, P. J.

Manovich, D.

McDonald, J.

McLendon, J. D.

Mills, J. M., Jr

Noey, J. L.

Oliphant, G. W.

Olmstcad, C. R.

Phillips, L. R.

Pohto, H. A.

Ross, W. D.

Smith, J. H.

In addition, this report is distributed in accordance with the categories UC-37, Instruments, and UC-38, Engineering and Equipment, as given in the USERDA Standard Distribution Lists for Unclassified Scientific and Technical Reports, TID-4500. 